\title{
Globalization and Decent Work: \\ Options for Panama
}

Working Paper No. 3

Philippe Egger

\author{
Policy Integration Department \\ National Policy Group \\ International Labour Office \\ Geneva
}

October 2002

Working papers are preliminary documents circulated

to stimulate discussion and obtain comments 



\section{Contents}

Preface iii

Introduction I

1. Economic growth and macroeconomic policy 2

(i) A slow growing economy . .................................................3

(ii) Causes of the relative decline of the non-services economy........................5

(iii) Consequences of a slow growing services economy $\ldots \ldots \ldots \ldots \ldots \ldots \ldots \ldots \ldots \ldots \ldots$

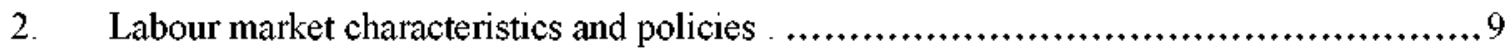

(i) Trends in labour force and employment ..................................... 9

(ii) A growing share of urban informal sector employment ...................... 10

(iii) High and persistent unemployment ............................................ 12

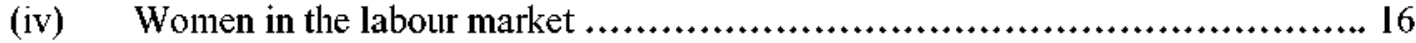

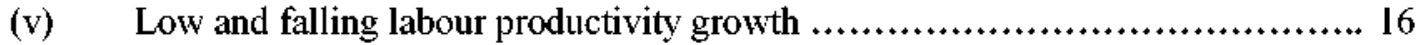

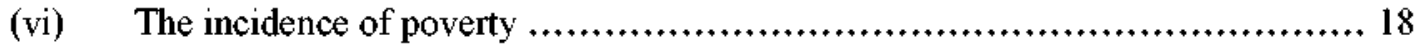

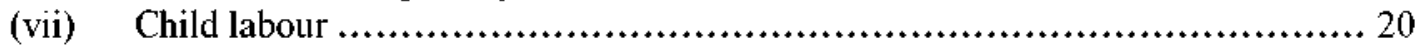

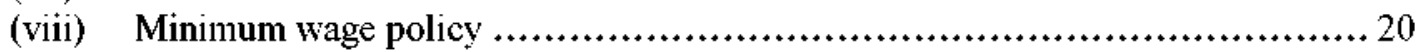

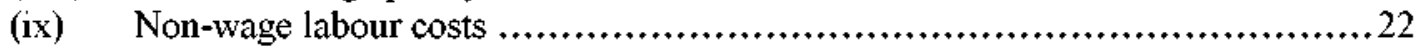

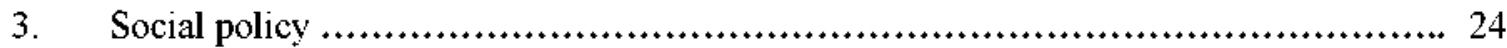

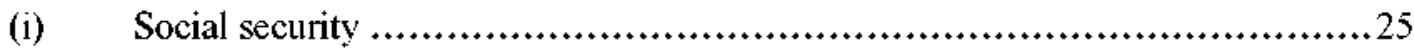

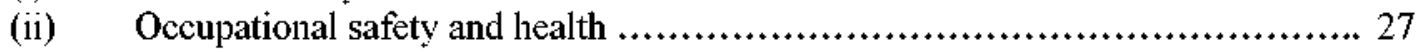

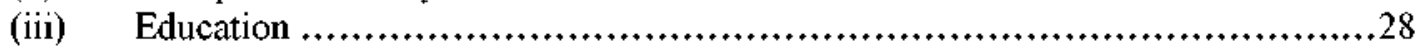

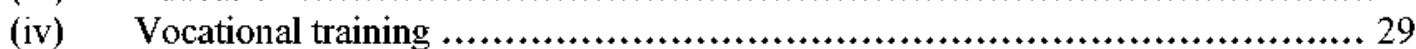

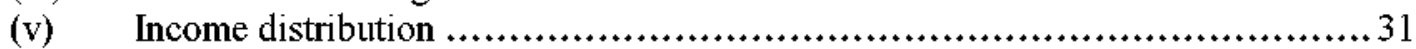

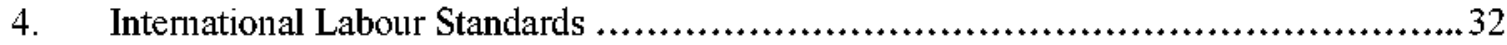

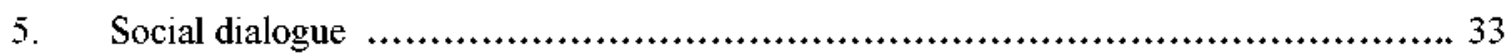

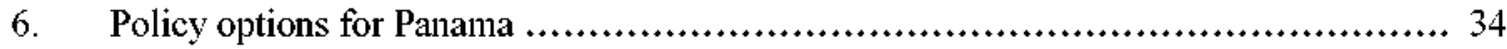




\section{Preface}

For some time, the ILO has been an active contributor to the debate on globalisation. Perhaps its tripartite composition alerted it earlier than other international institutions to the benefits but also to the costs of global economic and social integration. More recently the ILO has established a World Commission on the Social Dimensions of Globalisation mandated to deliver a set of proposals by mid-2003 on a more inclusive globalisation acceptable and fair to all. These debates find direct resonance in Panama.

As many other countries, Panama illustrates both the opportunities of globalisation and its social and economic costs. In spite of its privileged geographical location, Panama struggles to adapt its economy and society to the global economy. The benefits of economic growth have been and are unequally shared, and some areas and groups have shouldered a disproportionate burden in the restructuring implied by greater openness. This is hampering Panama's ability to achieve faster economic growth, greater social cohesion and higher standards of living.

The ILO response to globalisation is decent work, or greater opportunities to secure a decent job with an adequate level of social protection and a voice in decision-making. Hence, this study examines the situation in Panama from the point of view of decent work. It is a forward looking analysis in the sense that it seeks to identify some of the main policy areas that would need to be addressed for Panama to combine economic growth and social development. Looking at a country from a decent work perspective not only draws attention to what needs to be addressed, in terms of the combination of economic growth and employment, social protection, labour standards, and social dialogue. It also points to how these intertwined issues can be addressed. In this Panama is a clear illustration of how neglect in one area, such as social policy, undermines the promotion of other areas, such as economic growth. These dichotomies have become more problematic in the context of globalisation, as economies and societies are challenged to adapt more rapidly to external forces. ILO constituents have repeatedly called on the Office to assist them in addressing these challenges.

Policy integration in the sense of spelling out the implications of distinct sectoral policies on actual outcomes as well as the coherence between these policies in the sense of adding up to a whole enabling a country to move forward is very much an issue on the decent work agenda. Interestingly, it appears to be an issue in Panama. An appropriate policy mix has so far been interpreted in strict macroeconomic terms. In view of the importance gained and increasingly given to social issues, including labour matters, this mix has to be rethought in terms of broader economic and social objectives.

This study was carried out in the context of ILO's efforts to promote decent work and to spell out concretely what sets of policies hold the promise of achieving that objective. Panama is one of an initial set of countries where the ILO and its constituents have agreed to explore the manifold dimensions of a decent work agenda. This has implied in the course of essentially 2001 intense collaboration between the Government of Panama, principally the Ministry of Labour and the Ministry of Finance and Economy, the national employers' organisation (CONEP) and the national trade union coordinating body (CONATO), the Social Security Fund, and the ILO, both its Office in San José and several units at its headquarters in Geneva. A series of workshops and meetings have been organised during the year 2001 and into early 2002 to consider the various studies and reports produced by the decent work 
programme and to engage in genuine tripartite discussions of topical policy issues fed by the analytical work carried out.

We are indebted to Enrique Bru, Director of the ILO Office in San José and to Miguel del Cid, coordinator of the decent work programme in Panama, as well as to M. Muqtada of the Employment Strategy Department, Employment Sector for the excellent collaboration that made this work possible.

Readers interested in issues of globalisation as well as those motivated by the notion of decent work will form natural audiences for the analysis and messages found in this paper. Comments and reactions are always welcome.

July 2002

Gerry Rodgers

Director

Policy Integration Department 



\section{Introduction ${ }^{1}$}

Globalization had been a feature of Panama's history long before this term passed into daily use. The Panama Canal, opened in 1914, remains today a lifeline of international maritime transport. Its reversion to national control in 1999 has, if anything, underscored its global character. Panama also lends its flag to a sizeable merchant shipping fleet, most of which is owned and operated by non-residents. Finally, Panama has woven tight linkages with the international financial community through its banking centre. In many ways, Panama's economy is intimately dependent on global economic trends and thus vulnerable to external shocks, particularly in relation to the North American business cycles. Yet Panama is also a relatively late liberaliser, with full-scale liberalization of imports, intervening in effect only since 1997, when all tariffs were reduced to a maximum rate of 15 per cent, in the wake of it's joining the World Trade Organization.

In several ways, Panama is distinct from the rest of Central and Latin American economies. It adopted the US dollar as its currency very early in the 20th century, and therefore has no central bank nor is exposed to any foreign exchange risk. Largely due to this, its rate of inflation, as measured by consumer prices, averaging I-2 per cent per year over the last several decades, is low by international standards, not to speak of regional ones. In spite of these singular features, Panama shares much of the same predicament as other countries in the region. It experienced sluggish growth during the $1980^{\circ} \mathrm{s}$, a decade that ended with a military invasion deposing a military dictatorship, partly due to a mounting fiscal deficit and external public debt. Panama entered into a structural adjustment process with the assistance of the IMF in ways similar to the rest of the Latin American region. Macroeconomic stability returned in the early $1990^{\circ} \mathrm{s}$, and with it positive rates of economic growth following a deep recession in 1987-89. GDP growth has on average been higher in the 1990's than in the troubled 1980's. Yet growth has not been anywhere sufficient to generate employment in line with the growth in the labour force, to avoid a bulging informal sector and to significantly raise real incomes. Like other countries in the region, Panama faces a significant gap between labour demand and labour supply. This can be seen in the stubbornly high unemployment rate, that has remained above twodigits for over a decade now (at an average of 13.9 per cent during the 1990's). It is also evidenced in the growing share of urban informal employment, where employment is more a necessity and comes under many forms, all with low levels of productivity and income. But Panama also faces a large employment problem, with around half of its labour force eking out a living at very low levels in both rural and urban areas. Finally, Panama faces a huge internal social debt, with levels of income inequality among the highest of Latin America.

These problems existed in Panama before full-scale liberalization and can in no way be attributed to it. However, as elsewhere, it was assumed that rapid trade liberalization would substantially lift the rate of growth of the economy by eliminating inefficiencies and boosting a more competitive economy. GDP growth did pick up substantially during the first half of the 1990 's, but petered out thereafter. Doubts can be entertained as to whether liberalization per se is the answer to Panama's ills. The question is not whether Panama should or not liberalize its economy. It is now an open economy, no longer an economy with a few open enclaves, and there are very good reasons to suggest that it should remain so. The real question is what policies are needed in Panama that would put it on the path of

1 The author is indebted to Enrique Bru and Miguel del Cid for careful guidance and fruitful discussions and to Catherine Saget and Anne Trebilcock for very useful comments. 
a high growth economy with a more equal participation in the benefits of economic growth.

This report takes the view of the ILO Declaration on Fundamental Principles and Rights at Work, adopted by the International Labour Conference in June 1998, stating that "economic growth is essential but not sufficient to ensure equity, social progress and the eradication of poverty" and therefore that "economic and social policies need to be mutually reinforcing" in order to create "broad-based sustainable development".

Based on the analysis of the economic, social and labour market data available in Panama, this report argues that trade and financial liberalization are necessary but insufficient measures to build a competitive economy. In particular, supportive macroeconomic as well as social and labour market policies, including enhancing fundamental principles and rights at work, are required to enable countries such as Panama to successfully integrate with the global economy. This is tantamount to a decent work policy agenda which the ILO is now actively promoting.

The macroeconomic policy framework adopted in Panama has not so far been able to sustain a high rate of growth of its economy, nor have its social and labour market policies lived up to the requirements of an open and competitive economy. In particular, social dialogue between employers' and workers' organisations and with the government has not yet proven to be a conduit for negotiating and agreeing essential reforms in spite of many attempts at doing just that. These conclusions are argued in the subsequent sections, based on an examination of the economic, social and labour market performance of Panama. The policy issues discussed here, although made in the context of one particular country, are of more general relevance. Indeed, many other countries in the region find themselves in similar situations and face very similar policy dilemmas.

Recent macroeconomic performance and policy options are considered in Chapter $\mathbf{I}$. Labour market policies and institutions, including training and wage policies are discussed in Chapter 2. Social protection policies are examined in chapter 3, followed by international labour standards and the role of social dialogue. The concluding section discusses policies to promote decent work, Panama's best option in the context of globalisation.

\section{Economic growth and macroeconomic policy}

\section{A middle-income country with extensive poverty and income inequality}

With a GNP per capita of 2,990 US dollars in 1998, Panama ranks precisely at the world average of middle-income countries. This is however substantially below the average for the Latin American and Caribbean region (3,860 US dollars). Yet the incidence of poverty in Panama (national poverty line headcount index) was 37.0 per cent in 1997 (World Bank, 2000), a relatively high level (Colombia's GNP per capita in 1998 was 2,470 US dollars, and its poverty rate was 17.7 per cent in 1992). In addition, urban informal sector employment, a proxy for low quality employment, is high in Panama, (37.3 per cent in 2000, and 39.1 per cent for women) although lower than the average figure for Latin America and Caribbean (46.9 per cent) (Panorama Laboral, 2000). This suggests that economic growth has not benefited the poor, either because the rate of growth has not been sufficiently high, that the pattern of economic growth has not been labour intensive enough, or that the distribution of the benefits of growth (which translates into income distribution) has been excessively unequal, or any combination of these. 


\section{i) A slow growing economy}

The overall growth performance in Panama has been disappointing over the last two decades. Gross domestic product increased at an average rate of 2.4 per cent over 19822000, well below the average of 3.5 per cent for the Latin America and Caribbean region. GDP per capita increased at an annual rate of 0.5 per cent over the same period, against 1.3 per cent for the regional average. The economy picked up during the 1990's (GDP growth of 4.5 over 1991-2000), following poor performance during the first half of the 1980's marked by rising indebtedness and a deep recession topped with political turmoil at the end of the 1980's (GDP growth of 1.7 per cent for 1982-86 and -6.2 per cent for 1987-89). Yet the strong recovery witnessed during 1990-94 (6.5 per cent GDP growth) was short-lived and growth performance has been disappointing as of 1995 (3.5 per cent for 1995-00).

Table 1: Macro-economic indicators

\begin{tabular}{lccccc}
\hline & \multicolumn{5}{c}{ Average annual rate of change } \\
\hline & $1982-86$ & $1982-2000$ & $1991-2000$ & $1990-94$ & $1995-2000$ \\
\hline GDP (1982 prices) & 1.67 & 2.40 & 4.49 & 6.45 & 3.45 \\
GDP per capita (1982 prices) & -0.40 & 0.47 & 2.11 & 4.54 & 1.73 \\
Gross domestic investment/1 & -8.14 & 3.30 & 13.38 & 37.30 & 7.07 \\
Private consumption/1 & 5.38 & 3.79 & 3.64 & 4.86 & 6.20 \\
Exports of goods and services/1 & -0.50 & 2.35 & 1.02 & 10.20 & -3.30 \\
Imports of goods and services/1 & -4.91 & 2.52 & 2.40 & 11.57 & -1.00
\end{tabular}

Note: 1/ deflated by GDP deflator, latest value is for 1999 .

Source: IMF, International Financial Statistics Yearbook 2001.

Figure 1: Real GDP per person

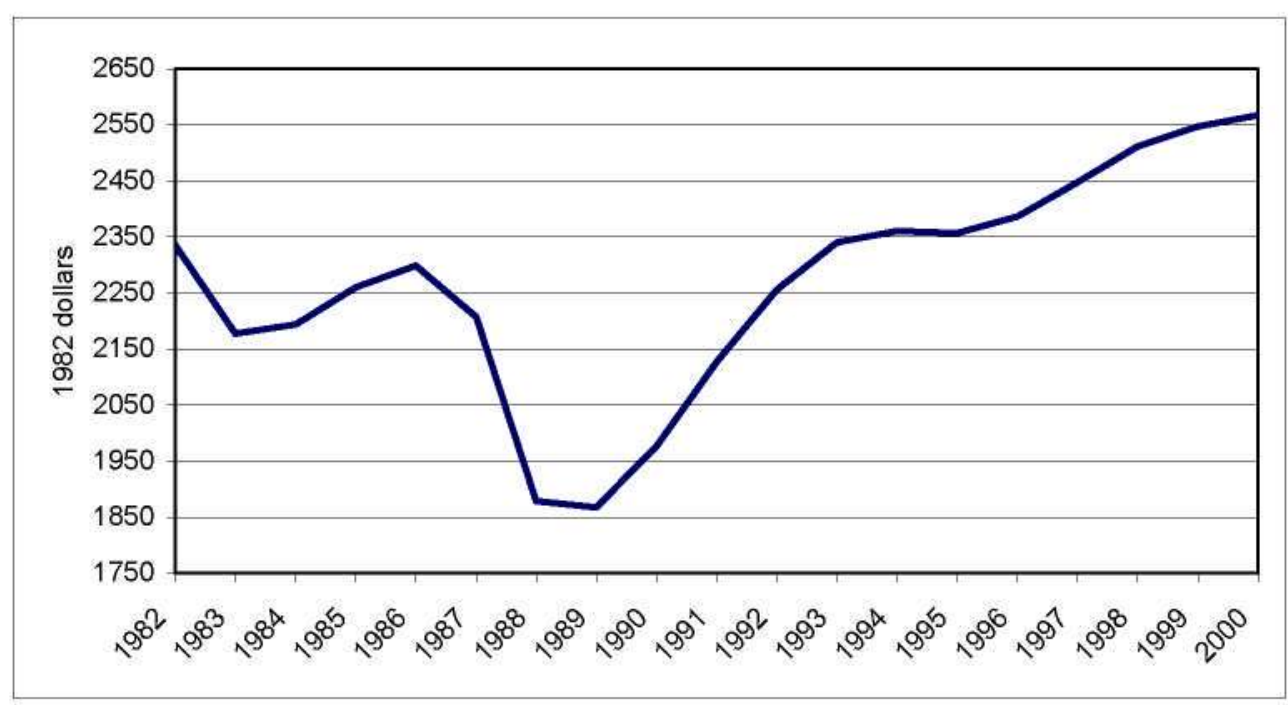

Source: IMF, 2001 
Looking at the trend in GDP per capita, the strong recession of the late 1980's is followed by an equally strong recovery, up to the year 1993, at which point the level of 1982 is reached again. Thereafter Panama registers two years of flat growth, followed by a modest recovery that is not sustained in 2000

Over the longer term, Panama's performance stands out as particularly lacklustre, on its own and in comparison with other countries of the region and outside the region. The comparison with countries in East Asia is particularly revealing. With an average annual increase in GNP per capita of 0.7 per cent, the performance over 1965-98, Panama would need 99 years to double its GNP per capita income level. The same could be achieved in only 11 years should Panama move to the rate of growth of GNP per capita registered by Singapore ( 6.4 per cent per year) over the same period.

Table 2: Panama in perspective

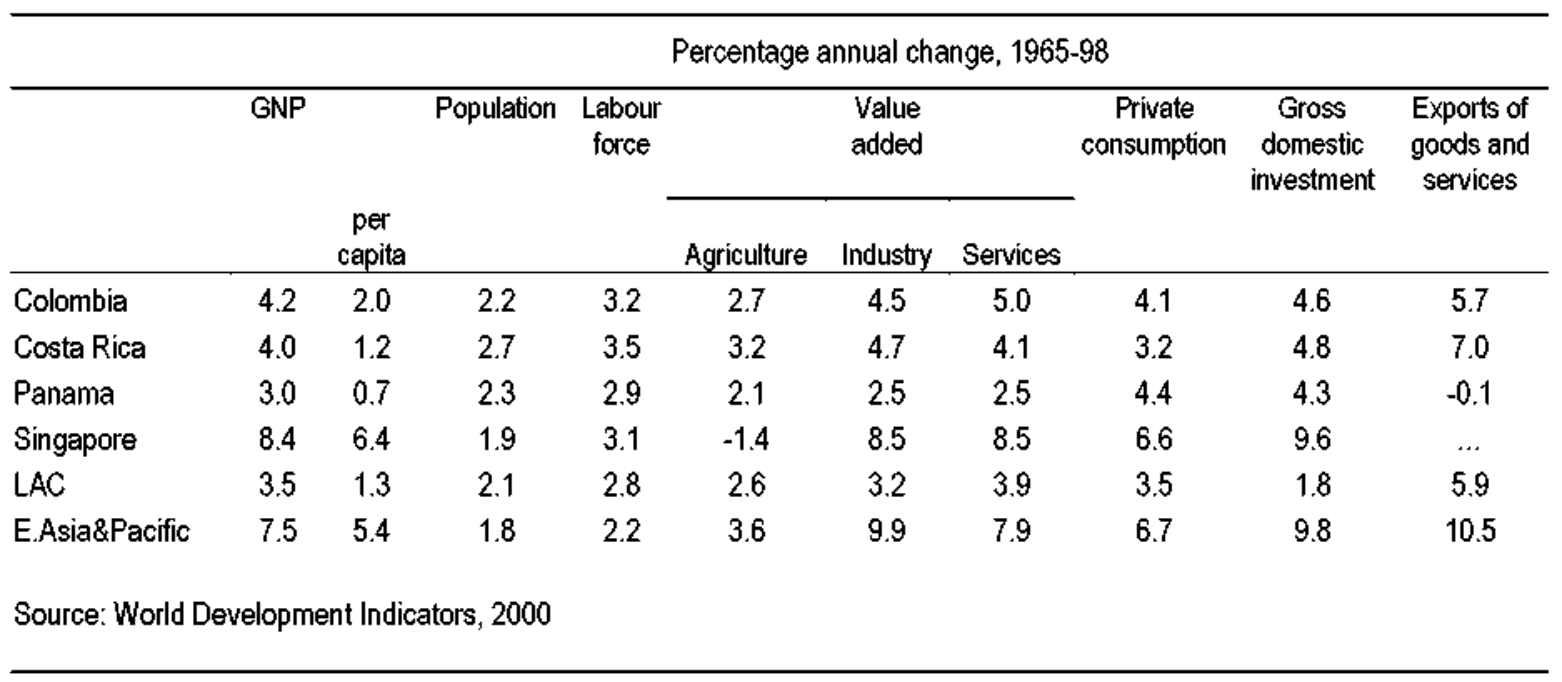

Why?

The main question therefore is why has Panama's economy registered such slow growth. With a privileged geographical position bordering on two seas, a vital link for international maritime transport, proximity to the major North American market, tropical weather with good soils, there is no a priori reason to believe Panama could not replicate an East Asian success story. But it is far from even nearing the rates of growth observed in East Asia up to the crisis of 1997. In addition, Panama has not experienced serious economic disequilibria in the form of high inflation or currency devaluations that have plagued so many other countries in the region. Neither is population growth a particular strain, as its rate of growth has been declining in line with the pattern observed in the region (the projected annual rates of growth are 1.2 and 1.3 per cent respectively for the period 1998-2015).

\section{Changing composition of output}

The fundamental reason for slow economic growth can be found in the recent economic history of Panama as a service economy. Specifically, Panama has over the last 30 years tended to consolidate the weight of the services sector in the economy, relegating the primary and secondary sectors to a marginal role. Between 1971 and 2000 , the combined contribution of the primary and secondary sectors to total output declined from 31.3 per cent to 25.6 per cent. The rate of growth of agriculture and industry over the longer term (2.1 and 2.5 per cent respectively for 1965-98) has been below the rate of 
growth of total output. It is also below the growth observed in Colombia and Costa Rica, and well below the rates registered in East Asia.

Between 1985 and 1999 , the composition of output has not substantially changed, with over 74 per cent of total GDP originating from the services sector, followed by the goods sector with 18 per cent and the agriculture sector contributing less than 8 per cent of GDP in 1999.

Table 3: GDP and employment by economic activity

\begin{tabular}{lcccccccc}
\hline & \multicolumn{3}{c}{ Relative participation by economic activity in } & \multicolumn{3}{c}{ Employment } \\
& 1985 & 1991 & 1995 & 1999 & 1985 & 1991 & 1995 & 1999 \\
\hline Agriculture & 8.64 & 9.02 & 8.24 & 7.52 & 29.46 & 26.66 & 20.80 & 17.43 \\
Mining & 0.08 & 0.09 & 0.14 & 0.24 & 0.06 & 0.10 & 0.18 & 0.09 \\
Manufacturing & 9.40 & 9.96 & 9.97 & 8.73 & 10.62 & 9.63 & 10.68 & 9.78 \\
Electricity & 3.94 & 4.26 & 4.21 & 4.81 & 1.45 & 1.22 & 1.02 & 0.73 \\
Construction & 3.21 & 2.48 & 4.19 & 4.47 & 5.31 & 3.25 & 6.18 & 7.59 \\
Trade & 16.26 & 20.41 & 20.73 & 18.91 & 13.89 & 19.87 & 20.72 & 23.11 \\
Transport & 13.30 & 13.01 & 12.33 & 13.87 & 5.96 & 6.91 & 7.32 & 7.59 \\
Finance & 26.42 & 22.33 & 24.01 & 25.77 & 3.89 & 4.17 & 5.41 & 6.59 \\
Services & 18.74 & 18.44 & 16.18 & 15.69 & 29.35 & 28.19 & 27.68 & 27.08 \\
Total & 100 & 100 & 100 & 100 & 100 & 100 & 100 & 100 \\
Source: ECLAC for & GDP and ILO and national sources for employment & & & & & & \\
\end{tabular}

The more recent period of the 1990 's confirms the relative decline of the primary and manufacturing sectors with rates of growth below the level registered for aggregate output. The dynamic sectors for the period have been mining, construction, transport, financial services and electricity.

\section{(ii) Causes of the relative decline of the non- services economy}

\section{Poor export performance}

A small country with a population of 2.8 millions in 1998, Panama is necessarily dependent on the external market for its growth. Up to the mid-1980's however Panama's economy was composed on the one hand of a tradable service sector, primarily the Canal, international banking and a dynamic free trade zone in Colón, the second-largest city after Panama City. On the other hand, there is a protected sector in non-tradables, consisting of agriculture, manufacturing, construction and services. In particular, relatively high tariff barriers in the import-substitution tradition protected agriculture and manufacturing. As in many other countries, there was little import substituting production, and much noncompetitive rent seeking. Incentives to export were few and certainly no counterpart to the tariff protection. As a result export performance was dismal. Over the longer period exports declined at a rate of -0.1 per cent per year. Following the recession of 1986-89 and the stabilisation measures introduced in 1990-92, exports grew at an impressive 5.2 per cent for 1990-94, but subsequently declined to 1.1 per cent over 1995-2000. Over the same periods, imports grew respectively at an annual rate of 7.2 per cent and 3.1 per cent. 
The first measures aiming to reduce tariffs on imports were taken in 1986. But it is only in 1997 with Panama's entry to the World Trade Organization, that the government reduced all tariffs to a maximum of 15 per cent. In 1998 the weighted mean tariff for all products was 8 per cent. There was no need to liberalize the capital account in view of Panama using the US dollar as its currency. The government's intention in lifting import tariffs was to introduce more competition in the domestic economy and to eliminate the rent-seeking activities that survived behind the high protection. Many governments in Latin America have liberalized imports virtually overnight as a means to lift the competitiveness of their economies. The question this raises in Panama as in other countries of the region is not whether open markets are more efficient than protected ones. Rather it is how countries should proceed to liberalize their imports within what time frame, content and sequence of policies. In the words of a recent document submitted to the ILO Governing Body:

"The gains from trade are undeniable as are the costs of protectionism, so the issue is not whether countries should benefit from freer trade but how this should be achieved." (ILO, 200lb).

In effect the "big bang" approach adopted by several countries in Latin America stands in stark contrast to the one adopted by countries in East Asia that have pursued selective export promotion policies first followed by gradual import liberalization later. This is well illustrated in the literature drawing the lessons from the fast growth of East Asian countries for the relatively slower growers in Latin America. ${ }^{2}$ What the East Asian experience suggests is that import liberalization per se cannot be seen as a sufficient measure to boost the competitiveness of an economy, neither for export oriented enterprises and sectors nor for activities competing with imports in the domestic market. At some point in the growth process, particularly for small countries with no domestic market to rely on, import liberalization is a necessary step. Yet, this should be one measure among a set of measures aiming to boost exports and strengthen sectors and enterprises competing with imports. Other important elements are the sequencing of measures, between export promotion and import liberalization and between the latter and capital account liberalization, as well as the overall macroeconomic context within which such measures are taken. Clearly, liberalization and tariff reductions are only one among a range of measures and policies required to raise the rate of growth of output.

\section{Exchange rate appreciation}

There are other reasons suggesting why import liberalization per se needs to be approached within a set of measures. Precisely because Panama faces no foreign exchange risk, it cannot resort to any exchange rate policy to stimulate exports and refrain imports. However, Panama is nevertheless subject to variations in the real value of the US dollar, which would affect not only its trade with countries outside the dollar zone, but also its terms of trade within the dollar zone (reflecting the relative import content of domestic production). In this way, the real multilateral exchange rate of the US dollar also reflects

$2:$... in the current world context of liberalization and globalization, the East Asians have been reluctant liberalizers. Contrary to the thrust of the Bretton Woods institutions, the East Asian countries during the last three decades have not sought close integration with the world economy but have instead sought what the present author has elsewhere termed a 'strategic integration'- that is, they have integrated to the degree to which and in the spheres in which it was in their interest to do so. Thus, they have traditionally been open with respect to exports but not so open with respect to imports." Ajit Singh, 1997. 
the competitive position of Panama's economy. During the 1985-97 period this indicator appreciated by 24.4 per cent, precisely during the time when Panama was liberalizing its imports (Jimenez, 2001). An appreciation of the real exchange rate of this magnitude is bound to have a strong incentive effect to imports and an equally strong disincentive effect to exports. A recent review of the experience with external liberalization suggests explicitly that such a combination should definitely be avoided (Berg and Taylor, 2000). It explains the poor growth performance of a number of countries that could not avoid it and the better performance of countries that did avoid it.

Interest rates

With no central bank and without any need to accumulate foreign reserves to pay for its external obligations, it would seem that interest rates would be exogenous in Panama. One should observe a tendency for interest rates in Panama (effectively commercial interest rates) to align themselves with international rates. But this is far from being the case. Commercial lending rates in Panama have hovered around 12 and 10 per cent during the 1990 's with an average of 10.9 per cent, approximately 50 per cent above the rates of around 5-6 per cent observed in the United States at the same time. The only reason that could explain such a difference would be any additional risk on credit present in Panama and not in the United States. And we have seen this cannot be found in any foreign exchange risk that is inexistent in Panama. In the absence of any national central bank whose monetary policy would guide credit policy of banks, these can only be guided by their own assessments of future trends in economic growth and intrinsic credit worthiness of each loan applicant. As a result it has been observed that credit to the private sector in Panama is highly pro-cyclical and in fact endogenous (Jimenez, 2001). Rates tend to rise during recessions and decline during periods of expansion. Commercial banks seem to be guided by their assessment of loan performance and their record of non-performing loans and arrears. These tend to be very cyclical. This points to another lesson from the recent experiences with liberalization. High domestic interest rates, combined with real exchange rate appreciation in a period of rapid import liberalization are a poor policy mix that is clearly counterproductive. Production costs and capital formation are penalized precisely at a time when enterprises are required to be more competitive.

Investment and capital formation

Gross domestic investment as a percentage of GDP averaged 27.8 per cent over the 1990's. Such a rate is close to East Asian levels known for their high investment/GDP ratios. However upon closer scrutiny, it appears that investment in construction, particularly housing, reaps the lion's share of domestic investment, with 54.2 per cent on average over the period, whereas capital goods other than transport equipment represent 28 . I per cent on average. Public investment is 15.5 per cent on average of total domestic investment in the 1990's (Jimenez, 2001). The question is why is there not more private productive investment that would increase the production potential of Panama's economy. High levels of investment relative to GDP are not, per se, sufficient to ensure sustained growth in the future if such investment is not attracted toward increasing the production potential of the economy.

\section{Fiscal balance and public debt}

As with many countries in the region, economic performance was lacklustre during the "lost decade" of the 1980 "s. Panama registered consistent and sizeable fiscal deficits between 1982 and 1989, from an average of 7.5 per cent of GDP in 1982-84 to 3 per cent in 1987-89. A positive balance was achieved during the high growth period up to 1995 , with only a moderate deficit up through 1998. The accumulation of sizeable deficits bloated the external public debt that reached 69.3 per cent of GDP in 1983, down to 48.2 per cent in 1993, and still 55.5 per cent in 2000. Such a public debt to GDP ratio is by no means unsustainable, but does represent a sizeable burden on fiscal capacity. A first 
structural adjustment programme was agreed with the IMF in 1982. A second severe fiscal adjustment was introduced in 1990 , following the military invasion. Only much higher levels of economic growth, based in particular on higher exports, would enable the country to reduce its debt to GDP ratio and recover space to raise domestic public investment

Figure 2: Fiscal balance

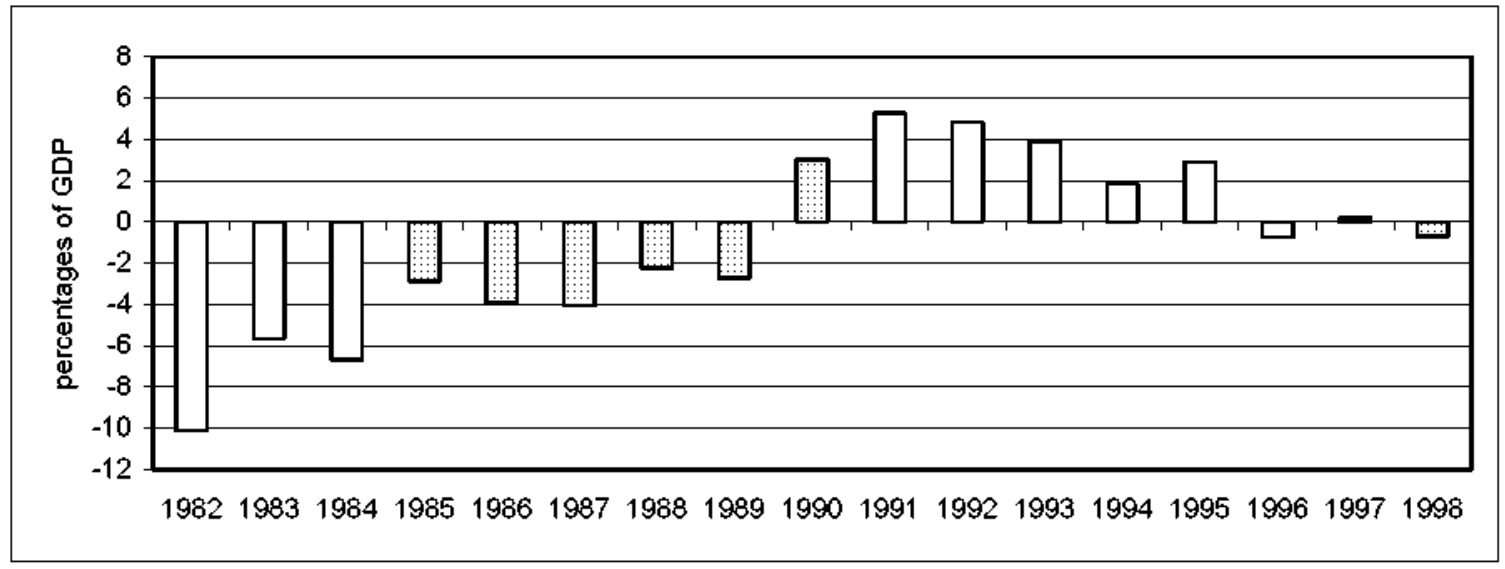

Source: IMF, International Financial Statistics Yearbook 2001

\section{(iii) Consequences of slow growth in a services economy}

\section{Liberalization without sustained growth}

Over the 1990s Panama's economy grew at an average rate of 4.5 per cent (1991-00), excluding the atypical year of 1990. During that same period, domestic investment increased at an average rate of 11.5 per cent. But growth was led by private consumption that increased at 5 per cent per year over the period, whereas exports only increased at a rate of 1.6 per cent, less than half the rate of imports. It is more than likely that the high rate of growth of domestic investment is linked to a construction boom, particularly private housing, fuelled by renewed confidence and greater availability of commercial credit. But a pattern of growth in which growth in private consumption exceeds total output growth, also reflected in imports rising faster than exports, is not sustainable. For an open economy to sustain a high rate of economic growth, it is necessary to achieve at a rate of growth of exports that is higher than the rate of growth of domestic investment, to avoid any liquidity constraint, and for domestic investment to grow at rate above the rate of growth of aggregate output. Panama meets the second condition, although the composition of domestic investment is not directed towards productive investment, but fails utterly on the first. The dismal export performance over the 1990 's is an indication that its growth path is not sustainable. Clearly, liberalization has not so far been able to boost exports, as evidenced by the growing deficit on the current account of the balance of payments. Panama does enjoy sizeable services and factor income, through the Canal and its merchant fleet, but not anywhere sufficient to finance its imports.

The stabilisation trap

The current account on the balance of payments has been registering a deficit throughout the 1990s. The deficit increased from an average of 1.7 per cent in 1990-95 to 9.3 per cent for 1996-00. Imports soared with the lower tariffs introduced in 1997 at the same time as exports grew only marginally. There are two ways to redress an unsustainable current account position. One is to compress aggregate absorption, through higher interest rates or reduced government spending for instance. This will tend to curb imports and 
restore some measure of equilibrium in the trade balance. This is the pattern observed during 1986-89. But as soon as demand picks up again, the deficit in the trade balance will rise and call for new measures to reduce domestic demand. Many Latin American countries are caught in such a stabilisation trap and are finding it difficult to move onto higher and more sustained growth paths (UN, 2001). Panama is no exception. An alternative route, based on the experience of East Asia, is to engage in a sustained effort to boost exports, in particular by rendering investment, including foreign investment, in export capacity more attractive.

Figure 3: Current account of the balance of payments and public debt

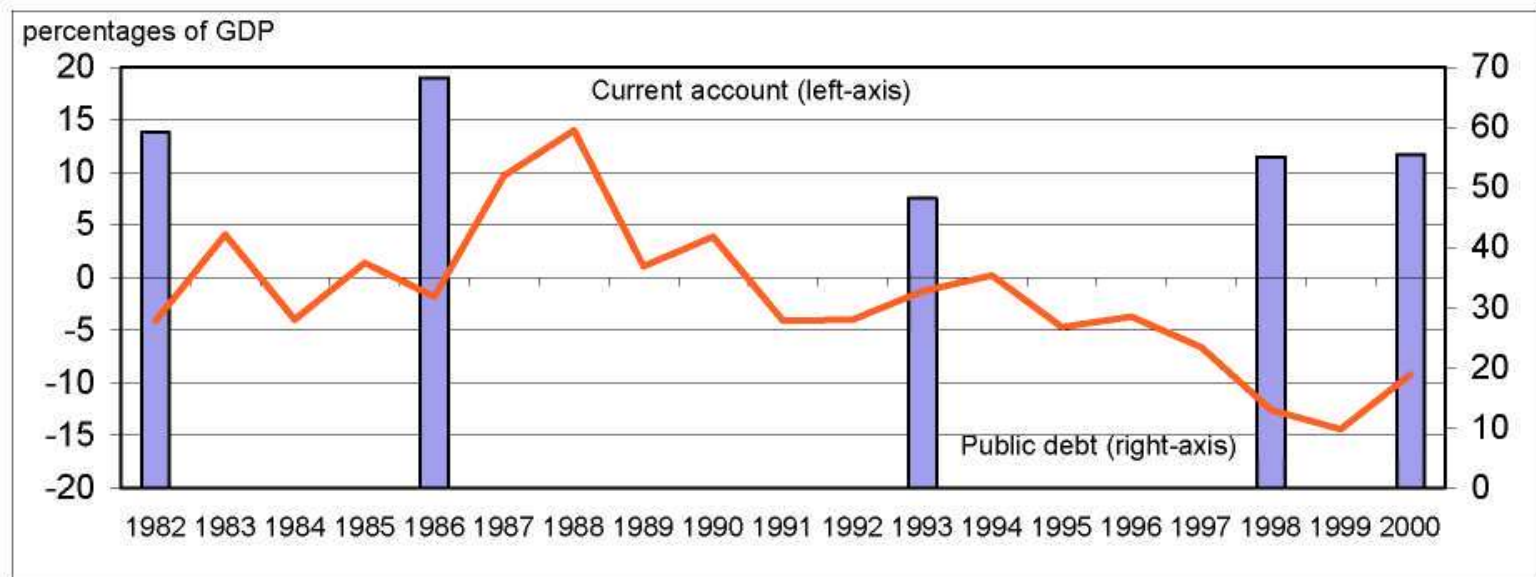

Source: IMF, International Financial Statistics Yearbook 2001

These economic trends have invariably left their mark on the labour market. These can be captured under four main headings, namely the dominance of services and trade in employment, a growing share of informal employment, high and persistent unemployment and low and falling labour productivity growth. The next section examines these issues.

\section{Labour market characteristics and policies}

\section{(i) Trends in labour force and employment}

In August 2000, slightly fewer than 1.1 million persons were in the labour force in Panama, of which 35.4 per cent women. In line with decelerating population growth, a regional feature indicating that Panama and Latin America are well advanced in the demographic transition, the working age population (here 15 years and over) increased at a rate of 3 per cent in the late 1980's dropping to 2.1 per cent in the late 1990 's. However, the labour force has continued to grow rapidly, up till 1995 , followed by a sharp drop in its growth in the 1996-2000 period, observed for both men and women. Had the labour force continued to grow at the rapid rate of the beginning of the 1990's, unemployment would have been much higher than the 13.3 per cent registered for 2000. The labour force participation and employment rates for women are roughly half that of men in Panama, although women have been joining the labour force at a rate much higher than men, whose labour force participation rates have stagnated, then increased and fallen again over the 1990 's, whereas those of women continued to rise. As a result, the unemployment rates of women are much higher than those of men. As we have seen, the rate of growth of formal employment was lower than that of informal employment. Employment growth was concentrated in the services sector and in construction. 
Table 4: Labour market indicators

\begin{tabular}{|c|c|c|c|c|c|c|c|c|c|}
\hline & \multicolumn{3}{|c|}{ Employment rate } & \multicolumn{3}{|c|}{ Labour force participation rate } & \multicolumn{3}{|c|}{ Unemployment rate } \\
\hline & Male & Female & Total & Male & Female & Total & Male & Female & Total \\
\hline 1985 & 71.4 & 29.0 & 49.9 & 78.8 & 35.6 & 56.9 & 9.4 & 18.4 & 12.3 \\
\hline 1991 & 67.2 & 29.6 & 48.1 & 77.1 & 38.2 & 57.4 & 12.8 & 22.6 & 16.1 \\
\hline 1995 & 72.5 & 34.0 & 53.1 & 81.3 & 42.5 & 61.7 & 10.7 & 20.1 & 14.0 \\
\hline 2000 & 70.3 & 34.2 & 51.9 & 78.8 & 41.6 & 59.9 & 10.8 & 17.9 & 13.3 \\
\hline
\end{tabular}

\begin{tabular}{|c|c|c|c|c|c|c|c|c|c|}
\hline \multicolumn{10}{|c|}{ Average annual percentage change } \\
\hline & \multicolumn{3}{|c|}{ Total } & \multicolumn{3}{|c|}{ Female } & \multicolumn{3}{|c|}{ Male } \\
\hline & $1985-89$ & $1991-95$ & $1996-00$ & $1985-89$ & $1991-95$ & $1996-00$ & $1985-89$ & $1991-95$ & $1996-00$ \\
\hline Population 15+ & 3.0 & 2.2 & 2.1 & 3.0 & 2.0 & 2.3 & 3.0 & 2.4 & 1.9 \\
\hline Labour force & 3.5 & 4.1 & 1.8 & 4.6 & 4.8 & 2.3 & 2.9 & 3.7 & 1.5 \\
\hline Employment & 2.3 & 4.7 & 2.1 & 3.6 & 5.6 & 3.0 & 1.7 & 4.3 & 1.6 \\
\hline Unemployment & 11.0 & 0.5 & -0.1 & 8.8 & 1.8 & -0.5 & 12.8 & -0.7 & 0.3 \\
\hline Source: SIAL/L & & & & & & & & & \\
\hline
\end{tabular}

\section{A services economy}

The consequence of a composition of output dominated by services is naturally a predominant weight of the tertiary sector in total employment. Trade and services totalled 64.4 per cent of all employment in 1999 , but these generated 85.3 per cent of net employment over the 1991-99 period. This is somewhat lower than the share of services in total output (74.2 per cent in 1999). In 1999, employment in agriculture was 17.5 per cent of total employment, 2.3 times higher than its share in total output ( 7.5 per cent). Industry absorbed 18.2 per cent of total employment in 1999 , a share equivalent to its contribution to total output. The industrial sector contributed 27.4 per cent of total non-agricultural employment generation over 1989-99, a reflection of the dynamism of the construction sector.

\section{(ii) A growing share of informal sector employment}

The informal sector ${ }^{3}$ represented 30 per cent of non-agricultural employment in 1986 before the severe recession, 33 per cent at the peak of the economic cycle in 1993 and 37.5 per cent in 1999, a clear upward trend, but still lower than the average for Latin America (46.4 per cent). The rate of growth of informal employment (5.9 per cent on average) has been above that of formal employment ( 4.7 per cent) throughout the $1989-99$ period. Four out of every ten new jobs generated over the period were informal, with one in every four jobs an informal independent activity. In 1985-89, formal employment increased less than 1 per cent annually, a reflection of the crisis, whilst informal employment grew at 5.2 per cent annually. During the high growth period (1991-95), formal employment grew at a rate of 6.4 per cent, with informal employment growing even faster ( 8.3 per cent). In the following period, formal employment growth slows down to 2.6 per cent, and informal employment to 4.5 per cent.

3 The informal sector is here defined as the sum of own account workers, excluding professionals and technicians, domestic workers and workers in enterprises of up to 5 workers. Other definitions exist. For a recent review see ILO, 2002. 
The share of informal employment in non-agricultural employment in 1999 was above average in construction ( 48.3 per cent), commerce ( 44.1 per cent) and transport (53.2 per cent). The share of own-account workers is also above average in these sectors. The composition of non-agricultural informal employment is of interest. Between 1991 and 2000 the share of own-account workers has increased, whereas that of workers in small enterprises (up to 5 workers) and in domestic work has declined. This is clearly a sign of excess labour generating its own jobs in the informal sector, with low entry costs.

Figure 4: Changing composition within the informal sector

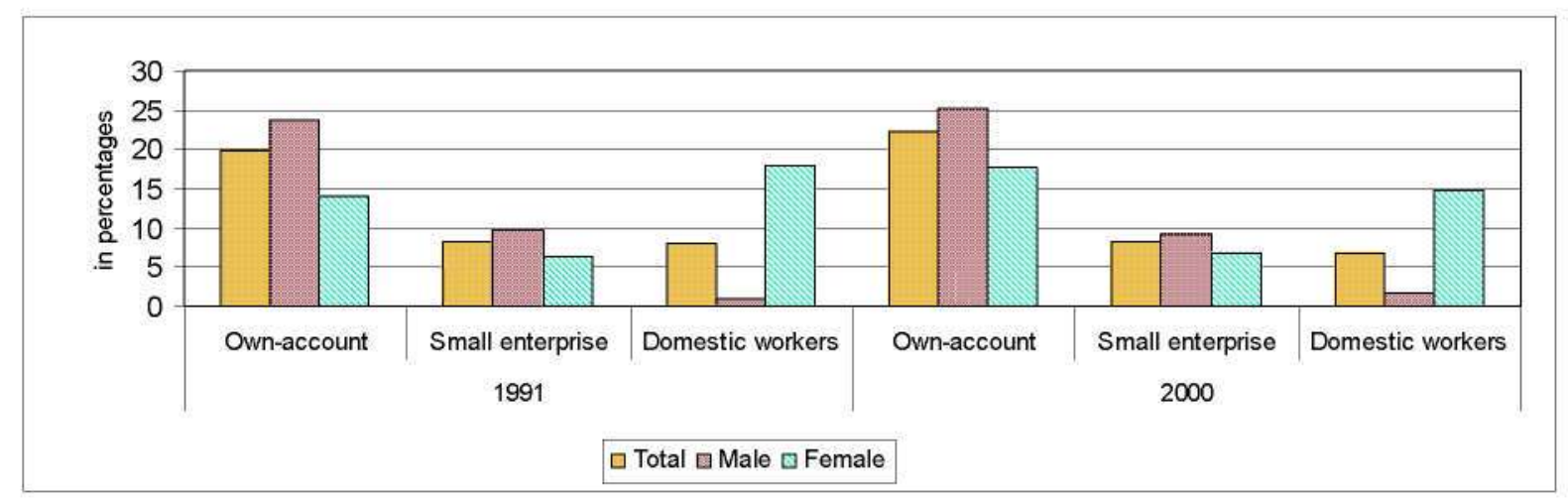

Source: ILO, Panorama Laboral, 2001

Informality is commonly associated with lower levels of productivity and earnings relative to formal sector earnings, and lower levels of protection. These features are also found in Panama were average informal income represents on average, for the 1991-99 period, 40.8 per cent of average formal sector earnings. The World Bank findings are very similar (World Bank, 2000).

Figure 5: Growth of non-agricultural employment (left axis) and share of informal employment and unemployment rate (in percentages, right axis)

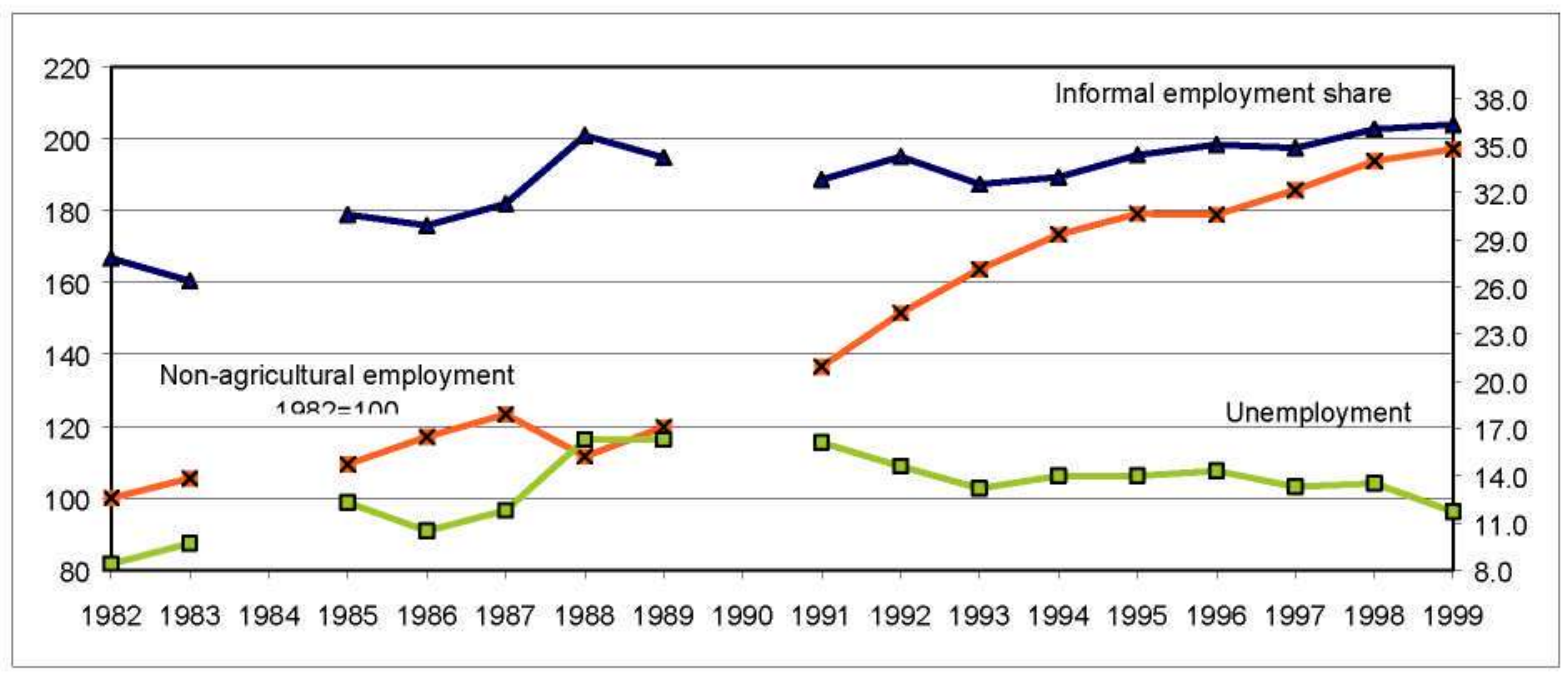

Source: SIAL/ILO

Note: No data are available for either 1984 or 1990

The World Bank (2000) survey finds a close overlap between poverty and informality. Some 70 per cent of all poor are active in the informal sector, and 80 per cent for poor women. Over half of all poor are wage workers, predominantly in the private sector, and 30 per cent are own-account workers, complemented by 17 per cent who are 
unpaid family workers, mostly assisting the former independent workers. In relative terms, more non-poor workers are found in the public sector and less as own account and unpaid family workers. One-fourth of all wage workers ( 26 per cent) perceive less than the hourly minimum wage, but 54 per cent of all poor wage-workers are in this case. Poor wage workers earn on average 42 per cent of the wage of a non-poor worker on a monthly basis, and somewhat less on an hourly basis ( 36 per cent)

Table 5: Status in employment and poverty

\begin{tabular}{lcc}
\hline & Poor & Non Poor \\
\hline Wage workers & 53 & 74 \\
Public sector & 6 & 22 \\
Private sector & 47 & 50 \\
Own-account workers & 30 & 24 \\
Unpaid family workers & 17 & 4 \\
Total & 100 & 100 \\
Source: World Bank, 2000 & & \\
\hline
\end{tabular}

There are various competing or complementary explanations for the growing informal sector in Panama as in other countries of the region. The first is based on labour force supply exceeding labour demand, with excess labour having to find employment in a low labour productivity sector in which wages are flexible and where employment is basically a function of supply. Urban labour force supply is a function of demographic growth, rising activity rates, particularly of women, plus the rural-urban migration fuelled by poverty in rural areas and the rural-urban income gap (agricultural incomes represent on average 51.5 per cent of non-agricultural incomes over 1991-99). A well-known underlying assumption here is that adjustment of nominal wages in the urban formal sector is constrained by exogenous factors. This is the analysis made by the World Bank linking the growth of the urban informal sector to labour market segmentation, specifically labour legislation in the form of minimum wages, non-wage benefits and high dismissal costs. The combined effect of this legislation is to raise the relative cost of labour in the formal sector and hence to ration its demand. Lower labour demand in the formal sector relative to total supply nurtures an informal sector in which wages are flexible and well below the level of the formal minimum wage ${ }^{4}$. An alternative explanation is to suggest that aggregate demand in Panama is constrained, due to a composition of output failing to make full use of Panama's comparative advantage, itself linked to the macroeconomic disequilibria discussed above. This is not to say that labour legislation has no effect on the level of formal employment in Panama or any other country or that any reform of the said legislation should be ruled out.

\section{(iii) High and persistent unemployment}

The third characteristic of the labour market is the unemployment rate. The unemployment rate jumps to over two-digits in 1985 (12.3 per cent) and has stayed above 10 per cent since. Total unemployment jumped by 11 per cent between 1985 and 1989 , a clear indication of falling employment during the recession years. The share of persons made redundant in total unemployment went from 60 per cent in 1986 to over 70 per cent in 1989. However, during the high growth period (1991-95) unemployment has fallen only very moderately from 16 to 14 per cent, and the share of redundancies in total

4 Product market regulations, in addition to labour market regulations, have more recently been identified as having similar effects, see OECD, 2002. 
unemployment has continued to rise, suggesting sizeable turnover in the labour market. This is in no way particular to Panama, as the combination of positive economic growth and rising unemployment appears to be a characteristic of Latin America during the 1990's (UN, 2001).

Figure 6: Rate of unemployment and share of dismissals

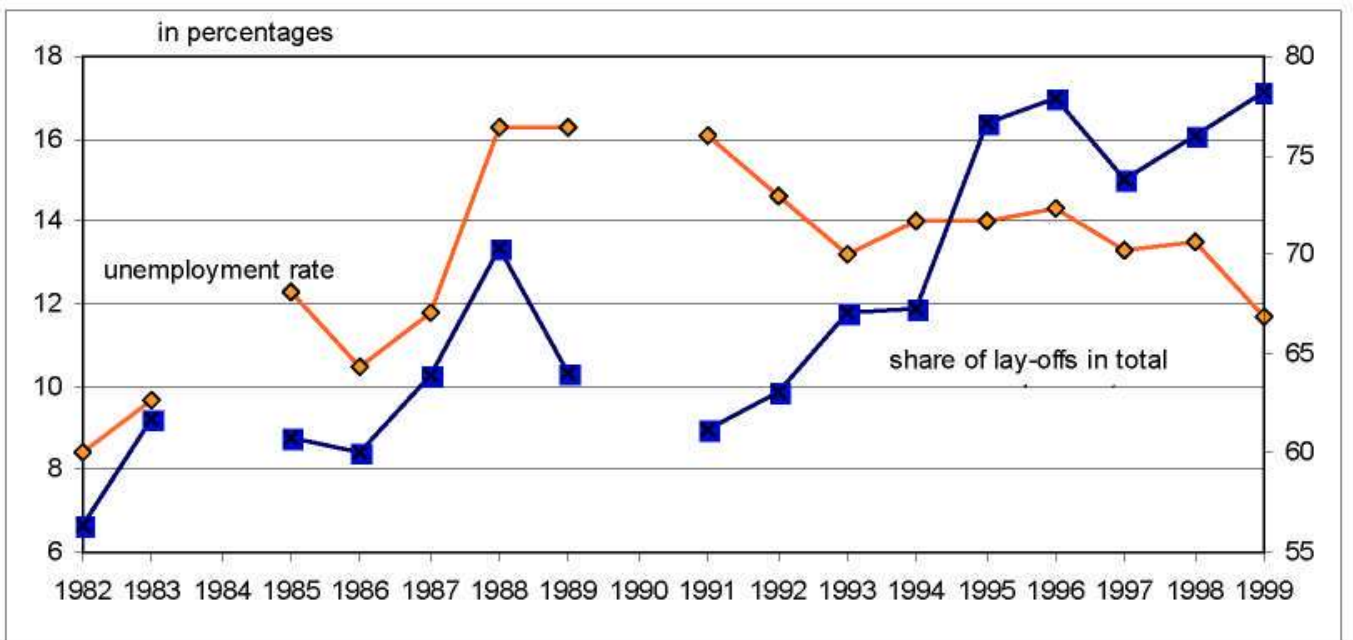

Source: SIAL/ILO

Part of the high unemployment can be explained by strong labour force growth, during 1985-89 (3.5 per cent) and during the high growth period (4.1 per cent during 199195), particularly female labour force growth, consistently higher than male labour force growth. However, labour force growth slowed considerably during the subsequent period (to 1.8 per cent during 1996-00), and unemployment fell only marginally to 13.3 per cent in 2000. Clearly, more than just cyclical forces are at work here, or else the rate of unemployment would have dropped considerably more than it actually has. There are several possible and competing explanations to Panama's high and persistent unemployment. The first is a classic case of mismatch between the skills in demand in the labour market and the level and characteristics of skills found in the labour force. Although the educational level of the labour force has been rising, it has possibly not risen enough and the educational and training systems are producing qualifications that are in low demand in Panama. Supportive evidence for this hypothesis can be found in the bell shape of unemployment rates by level of qualifications, lower for those with only primary education and with university education, and higher for those with secondary education, completed or not. 
Figure 7: Rate of unemployment and distribution of unemployed by education level

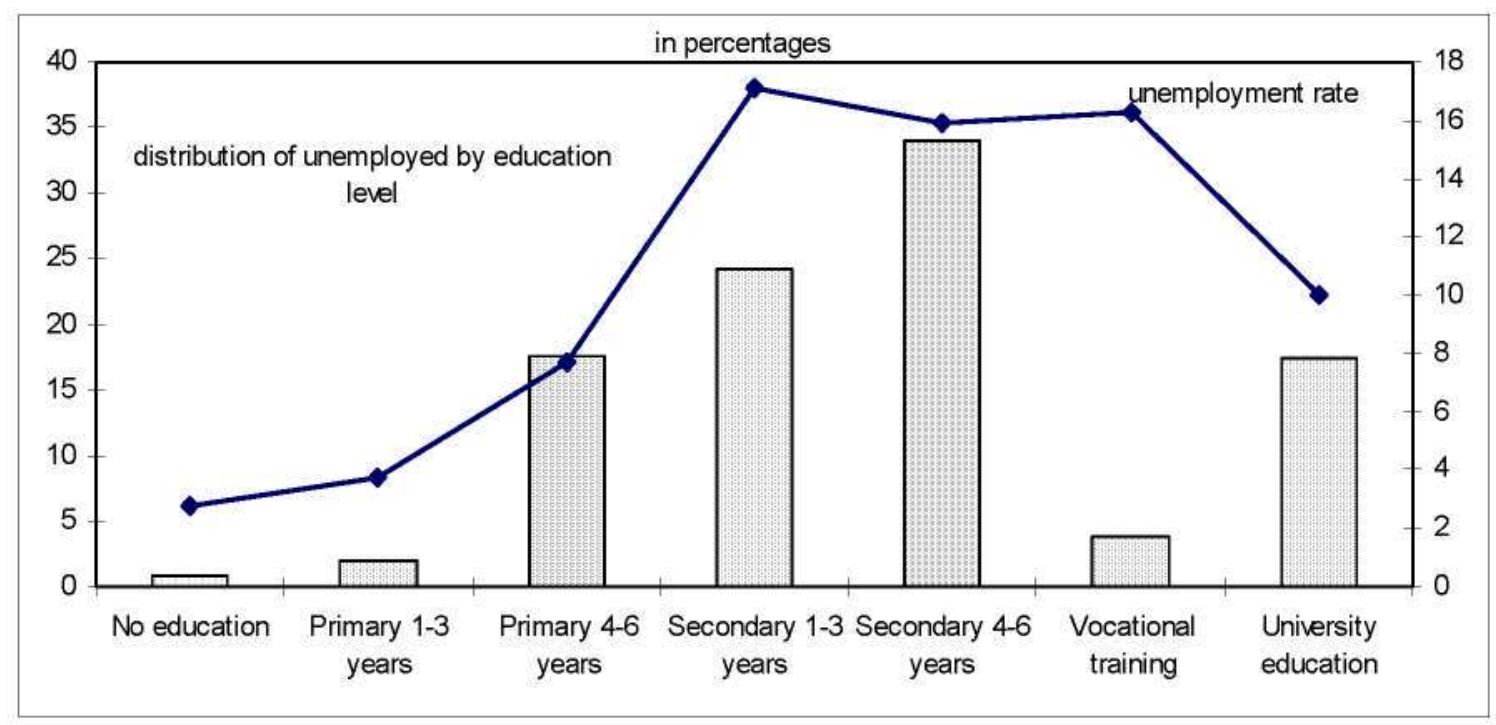

Source: SIAL/ILO

The second possible explanation is similar to the one for the existence of a large informal sector. It is linked to the Todaro (1971) hypothesis based on large wage differentials between the formal and informal sectors and the ensuing expectation of a formal sector job on the part of persons who would rather wait to find suitable employment in the formal sector than take up work in the informal sector. This hypothesis is of course linked to institutional factors constraining nominal wage adjustment in the formal sector. Todaro has refined this basic explanatory pattern suggesting that urban unemployment and hence rural-urban migration was basically a function of the rural-urban income differentials and the probability of obtaining an urban formal sector job. High urban employment growth and a sufficiently high elasticity of migration to the probability of finding a formal sector job could lead to an increase in urban unemployment and/or urban informal employment. Some of these forces are undoubtedly at work in Panama.

Real wage growth in the formal sector has not exceeded 0.7 per cent per year on average over 1991-99. Wage and earnings growth in the informal sector has been somewhat faster, with an average growth of 2.6 per cent over the same period. But the average informal sector wage represented in 1999 only 33.6 per cent of the average wage in the formal sector. Over 1991-99, this average was only 30 per cent. This substantial wage gap between the non-agricultural formal and informal sectors lends support to the Todaro hypothesis. It is also congruent with the positive correlation noted above between education levels and unemployment rates.

Another possible explanation is based on the level and composition of aggregate demand that is both insufficient and ill-adapted to absorbing the present level of labour supply. Sluggish growth in the primary and manufacturing sectors is a testimony of this. 
Figure 8: Non-agricultural formal and informal real wages and earnings

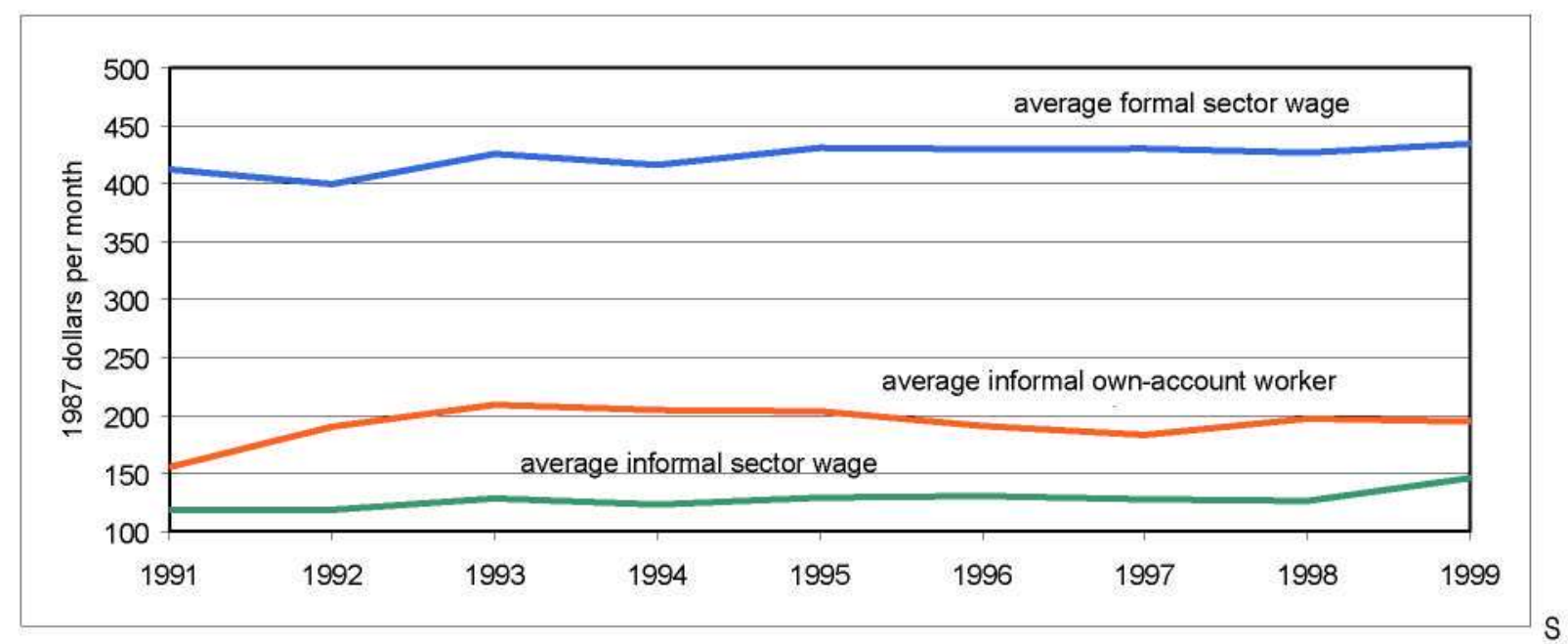

Source: SIAL/ILO

\section{Measurement of unemployment}

It is appropriate here to mention a methodological issue pertaining to the measurement of unemployment in Panama. The national labour force survey has been criticized by the World Bank (2000) for not adhering to the ILO defined criteria for surveying unemployment. In particular the labour force survey does not ask whether persons currently without unemployment are available for employment. The labour force survey defines three different categories of unemployed persons:

i) persons without work during the reference week and looking for work,

ii) persons without work, not looking for employment during the reference work but that have looked during the three months prior to the reference week,

iii) persons without work, and not looking for work neither during the reference week nor during the three months prior to it, for various reasons (looked earlier, were awaiting a reply, were discouraged).

The following table decomposes the unemployment rate according to these three categories for the period 1991-99.

Table 6: Decomposition of the rate of unemployment (in percentages)

\begin{tabular}{lccccccccc}
\hline & 1991 & 1992 & 1993 & 1994 & 1995 & 1996 & 1997 & 1998 & 1999 \\
\hline National definition (categories i), ii) and iii)) & 16.1 & 14.7 & 13.3 & 14.0 & 14.0 & 14.3 & 13.5 & 13.8 & 11.9 \\
Categories i) and ii) & 10.8 & 9.5 & 9.5 & 10.6 & 10.7 & 10.6 & 10.0 & 10.3 & 8.2 \\
Category i) & 7.9 & 5.6 & 6.3 & 7.5 & 7.3 & 7.6 & 6.9 & 7.4 & 5.5 \\
\hline
\end{tabular}

Source: SIAL/ILO

Persons without work and looking for work totalled 65 per cent over the period equivalent to an average rate of unemployment of 10.0 per cent. The main difference falls between persons without work and looking or not looking for work. It is possible hence that some of the persons registered as unemployed would not qualify as such were the ILO criteria fully applied (ILO, 1982). However, this is no relief from the fact that the aggregate employment rate in Panama (at 51.9 per cent in 2000) is low compared with 
other countries, and hence that there is considerable surplus and unused labour available that could be put to more productive use.

\section{(iv) Women in the labour market}

Women accounted for 35.4 per cent of the labour force in 2000 . Their position in the labour market reflects well-established determinants of gender segregation. The labour force participation rate of women is half that of men. More importantly, the labour force participation of poor urban women is only 74 per cent that of non-poor women. More than discrimination in wage and earnings, it is other forms of segregation that put women at a disadvantage in the labour market. The unemployment rate of women is higher than for men, especially among the young. There are proportionately more women than men in the urban informal sector, particularly in wage employment. Women are twice as likely than men to find employment in the services sector. On average women tend to earn 10 per cent less than men, but this would need to be refined with occupation-specific data also controlling for hours worked. The share of private sector female wage-workers is lower than for men, i.e. there are proportionately more low-paid men than women in private wage employment. However the reverse is true for own-account workers, where the share of women among the poorest 40 per cent is higher than for men, suggesting than women are concentrated in lower-paid activities.

There are clear male/female differences in the labour market in Panama. But these need to be crossed with the no less clear differences between poor and non-poor, including poor and non poor women. Over 40 per cent of employed (non-agricultural employment) women are in the informal sector. But facilitating greater labour force participation on the part of poor women may even represent a higher priority. Clearly, these two areas should be high on the public policy agenda in Panama.

Table 7: Women relative to men

\begin{tabular}{lcc}
\hline & Ratio & Year \\
\hline Labour force participation rate & 0.528 & 2000 \\
Employment rate & 0.486 & 2000 \\
Unemployment rate & 1.66 & 2000 \\
Youth unemployment rate & 1.73 & 1999 \\
Share of non-agricultural informal employment & 1.16 & 1999 \\
Share of non-agricultural informal wage employment & 2.16 & 1999 \\
Average formal sector wage & 0.898 & 1999 \\
Average informal sector wage & 0.865 & 1999 \\
Share of non-agricultural employment in services & 2.16 & 2000 \\
Poorest 40\% in private sector wage employment & 0.766 & 2000 \\
Poorest 40\% in own-account workers & 1.27 & 2000 \\
\hline
\end{tabular}

Source: SIAL/LO

\section{v) Low and falling labour productivity growth}

The last feature of the labour market is the trend growth in labour productivity. The combined effect of the growing share of commerce and services and of informal employment in non agricultural employment is to weigh on labour productivity growth, and hence on wage and earnings growth. Indeed, over the 1985-1999 period, aggregate labour productivity fell at an average rate of -0.51 per cent. In all but three sectors, agriculture, mining and electricity, employment has increased more rapidly than output, implying falling labour productivity growth. Only three sectors register positive labour 
productivity growth, but these account for less than 13 per cent of total output. In addition, rapid rural-urban migration rather than strong output growth explains the positive growth in labour productivity in the agricultural sector.

The implication of falling rates of labour productivity growth is that jobs are created at a pace out-stripping output growth. Growth has been highly labour intensive in Panama, particularly in the non-agricultural sectors, with employment elasticities close to or higher than unity. For the 1991-99 period, the aggregate employment elasticity was 0.8. But this implies less value added per employed person, hence lower wages and labour earnings. Less productive jobs are also lower quality jobs requiring lesser skills and offering less protection. Declining labour productivity is a sign both of a low relative contribution of the goods producing sector to total output, chiefly manufacturing and agriculture, as well as of the rising share of informal employment in the services sector.

Table 8: GDP, employment and GDP per employed person by economic activity (average annual percentage change)

\begin{tabular}{|c|c|c|c|c|c|}
\hline & \multicolumn{5}{|c|}{ GDP per economic activity } \\
\hline & $1985-91$ & $1991-95$ & $1995-99$ & $1991-99$ & $1985-99$ \\
\hline Agriculture & 0.78 & 2.58 & 1.73 & 2.15 & 1.56 \\
\hline Mining & 1.94 & 16.93 & 18.92 & 17.92 & 10.79 \\
\hline Manufacturing & 1.01 & 4.93 & 0.68 & 2.79 & 2.02 \\
\hline Electricity & 1.35 & 4.59 & 7.64 & 6.10 & 4.04 \\
\hline Construction & -4.15 & 19.57 & 5.78 & 12.46 & 5.02 \\
\hline Trade & 3.91 & 5.32 & 1.74 & 3.51 & 3.68 \\
\hline Transport & -0.31 & 3.49 & 7.22 & 5.34 & 2.88 \\
\hline Finance & -2.72 & 6.84 & 5.95 & 6.39 & 2.39 \\
\hline Services & -0.22 & 1.53 & 3.29 & 2.41 & 1.27 \\
\hline \multirow[t]{2}{*}{ Total } & 0.05 & 4.91 & 4.10 & 4.50 & 2.57 \\
\hline & \multicolumn{5}{|c|}{ Employment per economic activity } \\
\hline Agriculture & 0.63 & -1.53 & -1.81 & -1.67 & -0.69 \\
\hline Mining & 9.78 & 22.96 & -13.40 & 3.19 & 5.96 \\
\hline Manufacturing & 0.66 & 7.52 & 0.38 & 3.88 & 2.49 \\
\hline Electricity & -0.56 & 0.00 & -5.56 & -2.82 & -1.86 \\
\hline Construction & -5.71 & 23.02 & 8.03 & 15.28 & 5.77 \\
\hline Trade & 8.61 & 5.86 & 5.47 & 5.66 & 6.92 \\
\hline Transport & 4.85 & 6.28 & 3.59 & 4.92 & 4.89 \\
\hline Finance & 3.50 & 11.82 & 7.83 & 9.80 & 7.06 \\
\hline Services & 1.63 & 4.29 & 2.06 & 3.17 & 2.51 \\
\hline \multirow[t]{2}{*}{ Total } & 2.32 & 4.76 & 2.63 & 3.69 & 3.10 \\
\hline & \multicolumn{5}{|c|}{ GDP per employed by economic activity } \\
\hline Agriculture & 0.15 & 4.18 & 3.61 & 3.89 & 2.27 \\
\hline Mining & -7.14 & -4.90 & 37.32 & 14.28 & 4.55 \\
\hline Manufacturing & 0.35 & -2.40 & 0.31 & -1.06 & -0.46 \\
\hline Electricity & 1.92 & 4.59 & 13.98 & 9.18 & 6.01 \\
\hline Construction & 1.65 & -2.80 & -2.08 & -2.44 & -0.71 \\
\hline Trade & -4.33 & -0.51 & -3.54 & -2.04 & -3.03 \\
\hline Transport & -4.93 & -2.62 & 3.51 & 0.40 & -1.92 \\
\hline Finance & -6.01 & -4.45 & -1.74 & -3.11 & -4.36 \\
\hline Services & -1.82 & -2.64 & 1.20 & -0.74 & -1.20 \\
\hline Total & -2.22 & 0.14 & 1.43 & 0.78 & -0.51 \\
\hline
\end{tabular}

Note: Constant 1982 prices

Source: ECLAC for GDP and ILO and national sources for employment 
In 1997, one person in every three lived with an income below the national poverty line. The poverty rate (headcount rate) was 37.3 per cent according to the World Bank survey and 30.2 per cent according to an ECLAC estimate (CEPAL, 2001). The difference is attributable to methodological differences in setting the national poverty line and in the coverage and sampling of the surveys used, the Encuesta Nacional de Vida in the case of the World Bank and the household surveys in the case of ECLAC. Both surveys suggest that poverty is much higher in rural areas compared to urban ones. The incidence of poverty in 1997 using the World Bank survey was 15.3 per cent in urban areas, and 64.9 per cent in rural areas, but 95.4 per cent among indigenous people. Over 77 per cent of all poor were found in rural areas and close to 23 per cent in urban areas. The ECLAC source suggests furthermore that poverty has declined over the 1990's from 42.8 per cent in 1991 to 30.2 per cent in 1999 , an average decline of 4.3 per cent per year.

Table 9: Estimates of the incidence of poverty

\begin{tabular}{|c|c|c|c|c|c|c|c|c|c|c|c|c|c|}
\hline & \multicolumn{3}{|c|}{1991} & \multicolumn{3}{|c|}{$1994 / 95$} & \multicolumn{3}{|c|}{1997} & \multicolumn{3}{|c|}{1999} & \multirow[t]{2}{*}{ Sources } \\
\hline & national & rural & urban & national & rural & urban & national & rural & urban & national & rural & urban & \\
\hline $\begin{array}{l}\text { Mippe (1996) } \\
\text { World Bank } \\
(2000)\end{array}$ & 55 & 71 & 47 & 47 & 72 & 35 & 37.3 & 64.9 & 15.3 & & & & $\begin{array}{c}\text { Household survey } \\
\text { ENV } 97\end{array}$ \\
\hline $\begin{array}{l}\text { ECLAC (2001) } \\
\text { de JongNos } \\
(2000)\end{array}$ & 42.8 & 50.6 & 40.9 & 36.1 & 49.2 & 30.8 & $\begin{array}{r}33.2 \\
42\end{array}$ & $\begin{array}{l}41.9 \\
61\end{array}$ & $\begin{array}{r}29.7 \\
22\end{array}$ & 30.2 & 41.5 & 25.7 & $\begin{array}{c}\text { Household survey } \\
\text { ENV } 97\end{array}$ \\
\hline
\end{tabular}

The poverty reduction elasticity of per capita income growth according to ECLAC was -1.41 over 1991-99 in Panama, and -2.12 for extreme poverty. That is for every one per cent growth in per capita income, the poverty rate diminished by 1.41 per cent. On average in Latin America the coefficient of elasticity between per capita income growth and the poverty rate was -0.69 . Should Panama sustain a per capita income growth of 2.5 per cent per year (the average for $199 \mathrm{I}-00$ was 2.7 per cent), using the elasticity coefficient of poverty reduction calculated by ECLAC, 19 years would be needed to reduce by half the poverty rate of 37.3 per cent observed in 1997. Should Panama decide to abide by the objective set by the Millennium Declaration of reducing by half the extreme poverty rate of 18.8 per cent (1997) by 2015 , a GDP per capita growth of 2.1 per cent per year would be required. The objective of reducing by half the poverty rate of 37.3 per cent in 15 years would require a GDP per capita growth of 3.2 per cent per year on average. The magnitude of these challenges should not be underestimated. During the more recent period since 1996, per capita income growth in Panama dropped to 1.8 per cent. Clearly Panama needs to raise the rate of per capita income growth, or alternatively to raise the poverty reduction efficiency of economic growth, should it fully live to the Millennium Declaration commitment. The Millennium objective of reducing by half the extreme poverty rate seems more within reach than the parallel objective of reducing the overall poverty rate by half. However both objectives would require a serious reflection on poverty reduction and economic and social policies in Panama, as well as considerable commitment on the part of the Government and the social partners. 
Table 10: Years required to reduce by half the poverty rate under different GDP per capita rates of growth

\begin{tabular}{lcccc}
\hline & \multicolumn{3}{c}{ Overall poverty } & Extreme poverty \\
\hline GDP per capita growth & 1.5 & 2.0 & 2.5 & 2.1 \\
Elasticity coefficient/1 & -1.41 & -1.41 & -1.41 & -2.12 \\
Half of poverty rate/2 & 18.7 & 18.7 & 18.7 & 9.4 \\
Years required & 32 & 24 & 19 & 15 \\
\hline
\end{tabular}

Notes: 1/ECLAC source; 2/ World Bank estimate for 1997

Sources: ECLAC 2001, World Bank 2000 and own calculations

The World Bank has estimated the cost of eradicating poverty in Panama at approximately 5 percent of GDP or 10 per cent of total public expenditure in order to bring the living standards of all poor in Panama up to the poverty line in one year. This strikes as a rather modest figure compared to the estimates given above. The reason can only be found in the highly unequal income distribution found in Panama as well as in the relatively shallow depth of poverty.

\section{Rural poverty}

According to the World Bank survey of $1997,77.3$ per cent of all poor are located in rural areas that account for only 44.4 per cent of total population. The incidence of poverty in rural areas is 64.9 per cent. Any strategy to reduce poverty in Panama will need to address employment and living standards in rural areas. Rural poverty represents a massive loss of opportunities and productive resources. Agriculture contributes 7 per cent to total GDP but employs 22 per cent of the labour force, suggesting a large productivity gap. Income sources are clearly differentiated between the poor and the non-poor in rural areas. The poor are more dependent on agricultural activities ( 41 per cent of all income) for their income than on non-agricultural ones, whereas half of total income of the non-poor emanates from non-agricultural activities. The poor are also more dependent on wage labour in agriculture ( 15 per cent of total income of the poor).

Land distribution is unequal in Panama. Among all land-holders, the Gini coefficient of land holdings was 0.77 in 1997, close to the average in Latin America marked by substantial inequality. The poor own a third of all landholdings in Panama but represent over 66 per cent of the rural population. However, owning land is no guarantee of a higher income. Only 7 per cent of poor households own a land title. Most poor households own only very small plots of less than 5 hectares. In fact the incidence of poverty is higher among smallholders than among non-land holding rural households. Among the priority issues identified by rural communities are transport, roads and basic services (electricity, telephones, water and health). These can only be addressed through public investment in basic infrastructure. The scattered nature of rural communities in Panama is an added difficulty calling for clear priorities (World Bank, 2000).

Table 11: Income sources in rural areas, 1997

\begin{tabular}{lccc}
\hline (in percentages) & Poor & Non Poor & Total \\
\hline Agriculture income & 41 & 20 & 27 \\
Wage income & 15 & 6 & 9 \\
Self-employment & 26 & 14 & 18 \\
Non agricultural income & 35 & 50 & 45 \\
Non labour income & 23 & 29 & 27 \\
Total & 100 & 100 & 100 \\
\hline
\end{tabular}

Source: World Bank, 2000 
The incidence of child labour is not massive in Panama, with 8 per cent of children in the age group 10-14 years estimated to be working in 1997 (World Bank, 2000). Two thirds of all working children combine work and school attendance, with only 36 per cent working full time. But few children in these situations are likely to enter or complete secondary school. Hence the cost of child labour is lower education and the perpetuation of poverty. Child labour is concentrated in rural areas ( 73 per cent of all working children), predominantly in agriculture ( 46 per cent), and commerce ( 24 per cent), but also in community services and manufacturing, particularly for girls. Clearly child labour, in Panama as in many other countries, is an expression of poverty. It can be presumed that rising income per capita would gradually eliminate the need for families to rely on their children's contribution to total family income. However, child labour is as much an expression of the failure of social policy to target the needs of the poor, particularly with regard to education. Whether rising per capita income or better access to basic education will completely eradicate child labour is a moot point. Clearly both are required, as they will reinforce each other ${ }^{5}$.

\section{(viii) Minimum wage policy}

The Government determines the level of the minimum wage, in principle every second year, following the consultation of a tripartite minimum wage commission. Minimum wages have been left unadjusted between 1983 and 1992, whereas between 1993 and 2000 they were adjusted four times. In August 2000, there were 17 minimum wages in Panama, according to regions, economic activity and establishment size. The number of categories has changed over the 1990 's. The median value of the minimum wage corresponds to that applicable in small enterprises in manufacturing and trade. The lowest value is found in agriculture and the highest in the construction sector, both sectors were the standard deviation is highest. Between 1987 and 2000, the real value of the median minimum wage increased by 29.5 per cent. Between 1991 and 2000 the median minimum wage increased at an average annual rate of 4.7 per cent, whereas the average formal sector wage increased at an average rate of less than 1 per cent per year. In 1998, the median real minimum wage increased by 14.2 per cent. As a result, the value of the minimum wage as a percentage of the average wage increased. In 1999, the value of the minimum wage reached 61.0 per cent of the weighted average non-agricultural wage, up from 52.0 per cent in 1991, with a peak of 64 per cent in 1998. In comparison, the value of the minimum wage as a percentage of the median wage was in 199738.1 per cent in the United States, 39.6 per cent in Canada, 27.6 per cent in Mexico and 57.4 per cent in France (OECD, 1998). As a rule of thumb, an optimum combination between the coverage of the minimum wage and its level of protection is achieved when its value is approximately between 40 and 50 per cent of the median non-agricultural wage. It is estimated that in 1997 over 26 per cent of all wage workers in Panama earned less than the minimum wage, the bulk of which would be active in the informal sector (World Bank, 2000). In 2000, it can be estimated that 35 per cent of non-agricultural wage earners had earnings below the minimum wage.

5 A good assessment of the legal situation regarding child labour and the minimum age of admission to employment is found in ILO, 2000. 
Table 12: Minimum wages, $1987-2000$

\begin{tabular}{|c|c|c|c|c|c|c|c|}
\hline & \multicolumn{4}{|c|}{ Nominal } & \multirow{2}{*}{$\begin{array}{r}\text { Standard } \\
\text { deviation }\end{array}$} & \multirow{2}{*}{$\begin{array}{l}\text { Real } \\
2000\end{array}$} & \multirow{2}{*}{$\begin{array}{c}\begin{array}{c}\text { Percentage } \\
\text { change }\end{array} \\
1987-2000\end{array}$} \\
\hline & 1987 & 1991 & 1995 & 2000 & & & \\
\hline \multicolumn{8}{|l|}{ Agriculture } \\
\hline small enterprises & 122.71 & 122.71 & 143.51 & 166.40 & 40.3 & 146.09 & 19.1 \\
\hline large enterprises & & & 153.91 & 176.80 & 39.4 & 155.22 & \\
\hline Fishing & & & 174.71 & 176.80 & 39.4 & 155.22 & \\
\hline Mining & 172.63 & 172.63 & 207.98 & 253.76 & 37.9 & 222.79 & 29.1 \\
\hline \multicolumn{8}{|l|}{ Region 1} \\
\hline \multicolumn{8}{|l|}{ Manufacturing } \\
\hline small enterprises & 162.23 & 162.23 & 195.50 & 239.20 & 37.5 & 210.01 & 29.5 \\
\hline large enterprises & & & 207.98 & 253.76 & 37.9 & 222.79 & \\
\hline Electricity & 162.23 & 162.23 & 207.98 & 253.76 & 37.9 & 222.79 & 37.3 \\
\hline Construction & 189.26 & 189.26 & 259.98 & 312.00 & 42.2 & 273.92 & 44.7 \\
\hline \multicolumn{8}{|l|}{ Trade } \\
\hline small enterprises & 162.23 & 162.23 & 195.50 & 239.20 & 37.5 & 210.01 & 29.5 \\
\hline large enterprises & & & 207.98 & 253.76 & 37.9 & 222.79 & \\
\hline Transport & 162.23 & 162.23 & 207.98 & 253.76 & 37.9 & 222.79 & 37.3 \\
\hline Financial services & 162.23 & 162.23 & 207.98 & 253.76 & 37.9 & 222.79 & 37.3 \\
\hline Services & 162.23 & 162.23 & 207.98 & 253.76 & 37.9 & 222.79 & 37.3 \\
\hline Region 2 & 143.50 & 143.50 & 166.40 & 207.98 & 37.8 & 182.60 & 27.2 \\
\hline Region 3 & 133.10 & 133.10 & 166.40 & 207.98 & 37.8 & 182.60 & 37.2 \\
\hline Region 4 & 133.10 & 133.10 & 166.40 & 207.98 & 37.8 & 182.60 & 37.2 \\
\hline Region 5 & 122.70 & 122.70 & 143.51 & 187.20 & 38.7 & 164.35 & 33.9 \\
\hline Median value & 162.23 & 162.23 & 195.50 & 239.20 & & 210.01 & \\
\hline
\end{tabular}

Source: SIAL/ILO

The Minimum-Wage Fixing Convention, 1970 (No.131) not ratified by Panama, establishes that the elements to be taken into account when determining the level of minimum wages are the needs of workers and their families, and economic factors including the levels of employment and of productivity. Although the level at which the minimum wage is set is the result of intense consultations, it is not clear to what extent the above elements have been taken into account. An important aspect in the adjustment of the minimum wage is its predictability. This can be enhanced when based on clearly established criteria and on an established practice of social dialogue.

Figure 9: Real minimum wage (manufacturing, small enterprises) and ratio to the weighted non-agricultural wage

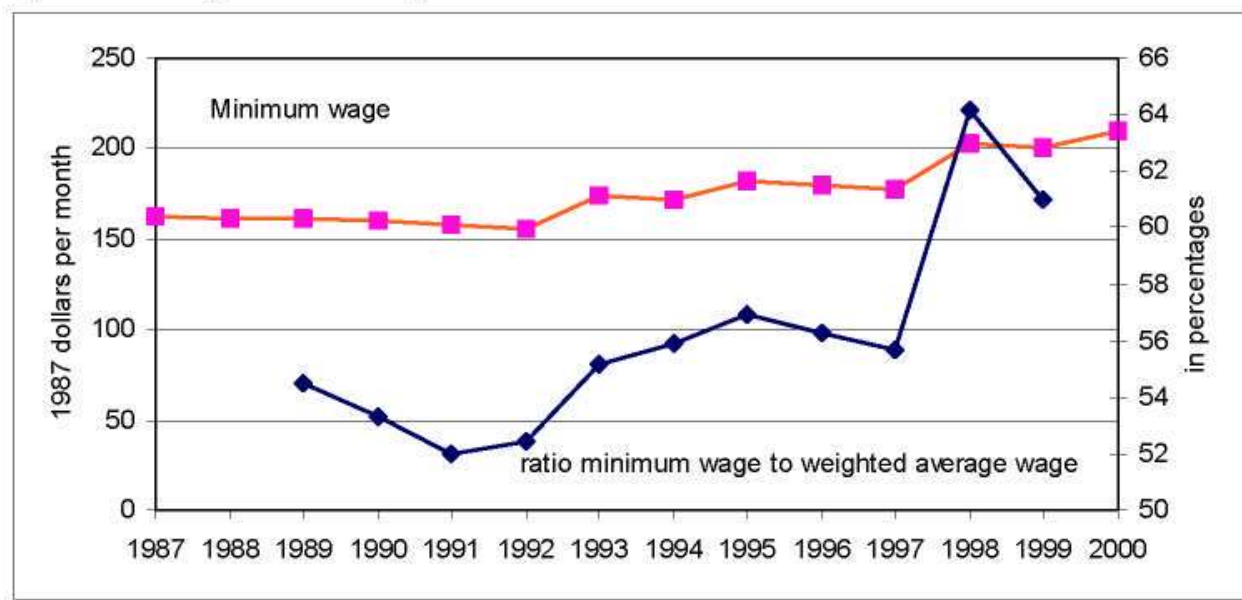

Source: SIAL/ILO 
A large informal sector and sluggish exports could point to high wage costs in Panama detrimental to both higher economic growth and higher formal employment growth. The compensation of employees has represented some 54 per cent of GDP at factor cost in the late 1990's, so the total wage bill is by no means negligible. One important factor in determining Panama's competitive position is whether non-wage labour costs are high relative to those found in other countries.

Table 13: Employer non-wage labour costs, as a percentage of the gross wage /a

\begin{tabular}{lcccc}
\hline & $\begin{array}{c}\text { Colombia } \\
1996\end{array}$ & $\begin{array}{c}\text { Chile } \\
1996\end{array}$ & $\begin{array}{c}\text { Mexico } \\
\text { Panama }\end{array}$ & $\begin{array}{c}\text { Pag5 } \\
1999\end{array}$ \\
\hline Family benefits & 4.0 & 0.0 & 0.0 & 0.0 \\
Wage benefits & & & & \\
Supplementary wage & 8.3 & 19.8 & 11.0 & 8.3 \\
Paid leave & 5.8 & 7.3 & 10.6 & 9.1 \\
Dismissal cost $/ \mathrm{b}$ & 9.3 & 8.3 & 2.0 & 2.3 \\
Social Security & & & & \\
Health & 8.0 & 0.0 & 8.8 & 8.0 \\
Pension & 10.1 & 0.0 & 6.0 & 2.8 \\
Occupational safety & 2.4 & 2.6 & 2.6 & 1.7 \\
Other benefits & & & & \\
Training & 2.0 & 0.0 & 0.0 & 1.5 \\
Housing & 0.0 & 0.0 & 5.0 & 0.0 \\
Family & 3.0 & 0.0 & 1.0 & 0.0 \\
Other & 0.0 & 0.0 & 2.0 & 0.0 \\
Total & 52.9 & 38.0 & 49.0 & 33.5 \\
\hline
\end{tabular}

la excludes holidays, maternity and sick leave costs and costs for unjustified dismissal $\mathrm{Hb}$ cost of termination of labour contract

Source: Tokman and Martinez, 1999 and 1997 and Ministry of Labour, Panama

A comparative assessment of employer paid non-wage labour costs as a percentage of the wage suggests that Panama is not overburdened with contributions over the gross wage. Indeed non-wage labour costs in Panama appear lower than those found in Chile, often cited as the most competitive economy in the region. By way of further illustration, on maternity leave not included in the above table, women workers affiliated to the social security system are offered 14 weeks leave at 100 per cent of the previous wage over the covered period. The length of the maternity leave is slightly above the average of 12.4 weeks found in Latin America.

However, it is quite possible that small enterprises find the total (employer and employee) non-wage labour costs (just under 48 per cent of the net wage) in Panama still too high relative to their paying capacity. Evidence from the World Bank suggests that only 50 per cent of all private sector employees in Panama perceive the $13^{\text {th }}$ month wage, mostly in the formal sector and among the non-poor. The following table details the total non-wage labour costs in Panama. 
Table 14: Total wage based contributions, in percentage points

\begin{tabular}{lccl}
\hline & Employer & Employee & Total \\
\hline Social security & 10.75 & 7.25 & 18.00 \\
Occupational safety & 1.65 & & 1.65 \\
Education & 1.50 & 1.25 & 2.75 \\
13th month & 8.33 & & 8.33 \\
Annual leave & 9.09 & & 9.09 \\
Sick leave & 5.77 & & 5.77 \\
Dismissal costs & 2.25 & & 2.25 \\
Total & 39.34 & 8.5 & 47.84 \\
\hline
\end{tabular}

Source: Ministry of Labour, Panama

It is worth pointing out that total social security contributions (social security and occupational safety) amounting to 19.65 percentage points account for 41.1 per cent of the total contribution rate of 47.84 per cent.

A different way to measure the competitiveness of the economy and whether total wage costs represent an explanatory factor in the economy's performance is to look at unit labour costs.

Table 15: Unit Labour Cost in Manufacturing, 1991-99

\begin{tabular}{lccccccccc}
\hline & 1991 & 1992 & 1993 & 1994 & 1995 & 1996 & 1997 & 1998 & 1999 \\
\hline Real wage (W/CPI) & 100 & 93.0 & 97.8 & 96.9 & 99.0 & 100.8 & 98.9 & 98.9 & 100.0 \\
Labour productivity (O/E) & 100 & 95.9 & 95.3 & 93.7 & 90.8 & 88.3 & 91.8 & 99.7 & 93.3 \\
Unit labour cost (W/CPIV(O/E) & 100 & 96.9 & 102.5 & 103.4 & 109.1 & 114.2 & 107.7 & 99.2 & 107.1 \\
\hline
\end{tabular}

Source: SIALILO

The above table depicts the flat trend in the real wage over 1991-99, the drop by 6.7 per cent in labour productivity and the consequent increase in the unit labour cost. It is interesting to observe that this increase in the unit labour cost in manufacturing is not due to any increase in the real wage, but rather to a fall in labour productivity. As it is not possible for Panama to adjust its external exchange rate, it can only increase its competitiveness with adjustments in labour productivity above those in the real wage. These data suggest that more than a labour cost problem, Panama has a labour productivity problem. The result in terms of lower competitiveness is the same, but the means to remedy it are not. Panama would not gain much reducing its labour costs in order to regain its competitiveness. This might in fact have adverse effects on labour productivity. Measures to raise labour productivity are varied, from investments in new technology to training, better health and working conditions, improved organization of work through greater cooperation and participation of workers, and less absenteeism. All are well-known instruments that need to be adapted to each case on hand. It is interesting to compare Panama with the situation in Colombia over 1990-97. Labour productivity in the manufacturing sector increased by 4 per cent on an average annual basis, leading to a fall in unit labour costs of 13 per cent. However, unit labour costs measured in dollars showed an increase of 54.3 in 1997 over 1990 due to an appreciation in the exchange rate for macroeconomic reasons totally independent of developments in the labour market (ILO, 1999). 
In comparative terms, employer paid non-wage contributions do not appear unreasonably high in Panama, although small enterprises may find it difficult to abide by the full provisions of the legislation. It is useful to recall here a provision of the Employment Policy (Supplementary Provisions) Recommendation, 1984 (No. 169):

"Members should take into account that integration of the informal sector with the formal sector may reduce its ability to absorb labour and generate income. Nevertheless they should seek progressively to extend measures of regulation to the informal sector".

Putting social security within the reach of small enterprises is a priority ${ }^{6}$. This can only be done progressively rather then as a fixed rate in principle applicable to all enterprises, large and small, formal and informal.

\section{Social policy}

Panama expends comparatively more in social areas as a percentage of GDP than the average in Latin America. With 19.4 per cent of GDP expended in social domains in 199899, Panama arrives in fourth position of 17 countries (average 13.1 per cent). This share has been stable at least since 1992. Expenditure on social security represents approximately 5 per cent of GDP. However, social public expenditure as a percentage of total public expenditure represents in Panama a significantly lower share (38.6 per cent in 1998-99) than the average in Latin America (47.8 per cent).

Panama enjoys relatively high health standards. Life expectancy is almost at 74 years at birth in 1999, higher than in Colombia ( 70 years) but lower than in Costa Rica (77 years). But it is only 63 years among the poor. The number of physicians per 100,000 people is relatively high, but it is estimated that some 20 per cent of the population has no adequate access to health services, using the WHO definition. There exists a degree of dissatisfaction among the population with respect to the quality and timeliness of health services. The under-five mortality rate at the national level is 21 in 1998, but much higher in rural areas with a high concentration of low-income households. This rate is almost twice the level registered in Costa Rica. A priority for Panama is to ensure a better distribution of health services, particularly in remote rural areas where the poor are located.

Table 16: Social indicators

\begin{tabular}{lccccc}
\hline & Colombia & Costa Rica & Panama & Singapore & United States \\
\hline Life expectancy at birth (years) & 70.9 & 76.2 & 73.9 & 77.4 & 76.8 \\
Adult literacy (\% pop. 15+) & 91.5 & 95.5 & 91.7 & 92.1 & \\
\hline Combined gross school enrolment (\%) & 73 & 67 & 74 & 75 & 95 \\
Under-five mortality (\%o) & 31 & 14 & 27 & 4 & 8 \\
Physician per 100,000 people & 116 & 141 & 167 & 163 & 279 \\
Human Development Index & & & & & 0.934 \\
\hline
\end{tabular}

Source: Human Development Report, 2000

6. The Recommendation concerning General Conditions to stimulate Job Creation in Small and Medium-Sized Enterprises (No. 189, 1998) provides much useful guidance in this respect. 
In 1997-98, the population covered by the social security system reached 64 per cent, and 54 per cent for the labour force. In 1992, the population covered was 53.3 per cent. This places Panama in $7^{\text {th }}$ and $6^{\text {th }}$ position respectively out of 19 countries in Latin America and the Caribbean in terms of coverage. Coverage varies greatly among the 10 provinces, between a high 77.3 per cent in Colón and a low 20.9 per cent in Darién. Nevertheless, 46 per cent of the labour force has no old-age, invalidity and death insurance and 32 per cent no health and maternity insurance, although some public health services are available to the non-affiliated population. The lowest rates of affiliations are typically found among the self-employed, particularly in small enterprises and in rural areas, the unemployed, domestic employees, and unpaid family workers. It is estimated that some 43 per cent of the 35,000 small and medium-size enterprises are not affiliated to the social security system, as well as some 11 per cent of all wage workers (ILO, 1998 and Mesa-Lago, 2000 ). Some 60 per cent of the non-affiliated population is located in only two provinces, Panamá and Chiriquí.

Total contribution to the social security is currently 20.45 per cent of the wage (unchanged since 1982), placing Panama in $12^{\text {th }}$ position in the region (Mesa-Lago, 2000), with 7.25 percentage points financed by the employee and 12.40 points by the employer. Voluntarily affiliated persons contribute a total of 18 per cent of labour earnings. Details of contributions by benefits are given below. The level of contribution places Panama in 12th position in the region, following higher contributions countries with both lower (Colombia, Mexico and Peru) and higher (Argentina, Costa Rica and Uruguay) levels of coverage with respect to Panama. The employee contribution is the $5^{\text {th }}$ highest in the region (1989 data) whereas the employer contribution ranks $\mathrm{II}^{\text {th }}$.

\section{Pension benefit}

The pension system is relatively generous in spite of a reform of 1991 that substantially curtailed the benefits for early retirement. The pension age is currently at 57 years for women and 62 for men, placing Panama in $8^{\text {th }}$ position in the region. Only 15 years of contributions are required to claim entitlement to the basic pension. The basic replacement rate is 60 per cent. In 1998 there were 5.2 active contributors for every pensioned person, a relatively low rate. Pensions are adjusted at the discretion of the State, in principle every three years, but there is no established methodology.

Table 17: Social security contribution rates (in percentages), 1999

\begin{tabular}{lllll}
\hline & Employee & Employer & State & Total \\
\hline Invalidity, old age and death & 6.75 & 2.75 & 0.00 & 9.50 \\
Health and maternity & 0.50 & 8.00 & 0.00 & 8.50 \\
Occupational risks & 0.00 & 1.65 & 0.00 & 1.65 \\
Administrative costs & 0.00 & 0.00 & 0.80 & 0.80 \\
Total & 7.25 & 12.40 & 0.80 & 20.45 \\
\hline
\end{tabular}

Source: Social Security Fund and Mesa-Lago, 2000

In 1996, a tripartite committee was established to examine the actuarial situation of the pension fund. The ILO was requested to establish financial and actuarial projections up to the year 2050 (ILO, 1998). The ILO study published in 1998, with an update issued in 2001 , foresees a deficit in the social security system, primarily in the pension fund by the year 2013-15, should no reforms be introduced. This projection holds under both low and high economic growth scenarios. The study establishes the need to increase the contribution rate to the pension fund from the current 9.5 per cent to 14.8 per cent in the 
absence of any reform, and to 14.1 per cent with reforms, including price indexation of pensions. Should no reforms be decided upon, the State would have to finance between 75 and 59 per cent of the total pension burden by the year 2050 . The ILO study found that the basic cause of the projected deficit in the pension fund was linked to the benefits reformed in 1991, when an optional early pension at age 50 for women and 55 for men was introduced.

Among the options for reform suggested for consideration (ILO, 1998 and MesaLago, 2000) are:

i) Extension of the years of contributions (over a long transitory period from the current 15 years to 25 years, slightly higher than the current average of 22.5 years of contributions);

ii) gradual reduction in the basic replacement rate from 60 to 50 per cent for the first 15 years of contribution, with a progressive rate thereafter in order to reward longer contribution periods;

iii) extension of the period of the highest average wage considered for the calculation of the pensionable income, from the current 7 years to possibly 15 years; and a

iv) gradual increase in the retirement age from the current $57 / 62$ years.

The gender implications of these recommendations would need to be spelled out.

To date no consensus has been reached between employers, workers and the government on any of the reform options. Workers tend to favour an increase in the contribution rate whereas employers are inclined towards longer contribution periods and greater efficiency in the social security system. Privatisation of the pension fund following the example of Chile and the introduction of private complementary pensions (now limited to public employees), are also among the options under discussion. The current government of Ms Moscoso has set up a new committee to examine the reform options and the ILO has been requested to update its 1997 projections.

No deficit is foreseen for the occupational injury fund over the forecasted period. Moreover, the current average contribution rate ( 1.65 per cent) is found to generate a surplus. It is estimated that this rate could be reduced to between 1.23 and 0.94 per cent, or even lower should more resources be expended in prevention.

\section{Toward universal social security coverage}

In the conclusions concerning social security adopted at its $89^{\text {th }}$ Session (2001), the International Labour Conference underscores as of "highest priority, policies and initiatives which can bring social security to those who are not covered by existing systems". To that effect, "each country should determine a national strategy for working towards social security for all" closely linked to its employment strategy and other social policies (ILO, 200 la). The conclusions further note that it is not always possible to ensure the same range of benefits to all categories of people, and that priority should be given to the more pressing needs as identified by the groups concerned.

These conclusions are particularly relevant in the context of Panama and its options to extend current coverage. This discussion must be placed in the broader context of the social policy of the government in Panama. Coverage is particularly low for the selfemployed. These account for an estimated one-fourth of the total uninsured population, which is at least 12 per cent of the total population. Self-employed are requested to affiliate voluntarily. A contribution of 18 per cent is currently required with no options in terms of 
benefits. In addition the administrative requirements are cumbersome. More options, lower contributions and simpler payment modalities would facilitate the participation of such workers, predominantly from the informal sector. Furthermore, the unemployed should be able to retain entitlements to benefits (especially in health) for a period (between 3-6 months). This would serve as an incentive to active job search. Finally, in 1997 only onethird of the population of 60 years and more, was entitled to social security health and/or pension benefits. This group is bound to increase with the combined pressure of ageing of the population and informalization of the labour force. Some basic pension entitlement financed out of tax revenue would certainly contribute to removing from the labour force some elderly persons, as well as lifting out of poverty those with an income insufficient to sustain them.

Universal coverage of basic benefits should form an objective for Panama, and the ILO should assist it in examining the available and feasible options.

\section{(ii) Occupational safety and health}

Rates of fatal injuries are comparatively high in Panama. The average rate of fatal injuries per 100,000 wage workers was 14 over the 1990's. This rate is lower in 1998 than in either Argentina or Brazil, but higher than in Colombia or Costa Rica. The rate is particularly high in the construction industry ( 52 fatal injuries per 100,000 wage workers) where it is greater than in either Colombia (2.2 times higher) or Argentina (1.3 times higher). In addition, one must assume a measure of underreporting given that close to 50 per cent of total employment in the construction industry is informal. There are no data indicating how many workers are specifically insured for occupational hazards in Panama. By comparison, in the European Union, the incidence of fatal injuries per 100,000 employed persons was 5.03 in 1998 , and 12.8 in the construction industry.

Figure 10: Rates of fatal injuries per 100,000 employees/insured workers

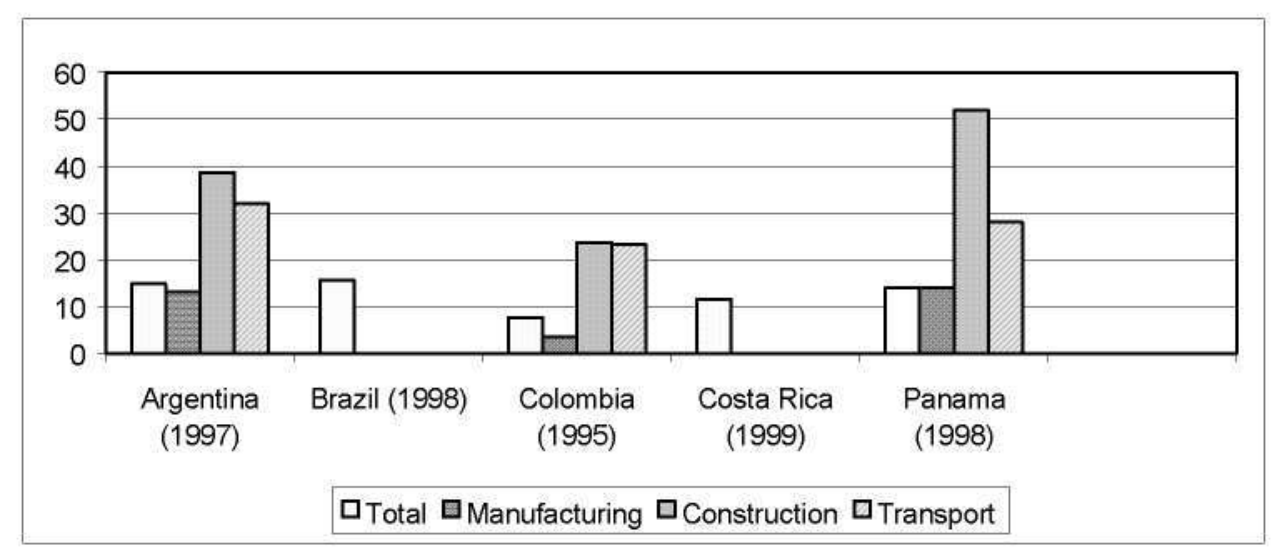

Source: ILO, Yearbook of Labour Statistics

In view of the current surplus in the occupational injury fund, Panama is registering a double cost: contributing more than required for the financial equilibrium of the occupational injury fund, and registering a high incidence of injuries. Clearly by spending more on prevention, Panama could enter a virtuous circle, with a lower incidence of occupational injuries and lower contributions to occupational injury insurance. For this to happen, employers and workers need to get more involved in promoting preventive measures at the work place. 
Should Panama decide to set itself the objective of cutting by half the incidence rate of fatal injuries in the construction industry over a period of 10 years (that is a level equivalent to twice of that found in the European Union in 1998), this would imply a reduction of 2.6 fatal injuries per 100,000 wage workers per year. This would represent a worthwhile objective for bipartite and tripartite dialogue.

\section{(iii) Education}

Education has been identified as an important correlate of poverty and of income inequality, in Panama as well as in many other cross-country studies both at the regional and world level (Morley, 2001). Access to education is highly unequal in Panama, between rural and urban areas, and between income groups. Lack of access to education, in terms of fewer years of schooling and lower quality education, is an important source and perpetuation of poverty. In 1997 the poor in Panama had on average 5.2 years of schooling against 9.5 years for the non-poor. The average number of years of schooling has increased substantially in Panama over the 1990 's. The share of employed with 10 or more years of education has increased from 39.2 per cent in 1989 to 47.2 per cent in 1999 . But these improvements have been unequally distributed. The population 25 years of age or more in the first quintile income group had 4.83 years of schooling in the late 1990's whereas the fifth quintile had 12.22 years of schooling. The ratio between the two extreme quintiles was 2.52 in the late 1990 's, an increase over 1989 when the ratio was 2.29 . Education inequality and skill differential increased in Panama as in the rest of Latin America over the 1990's (Morley, 2001). The net enrolment rate in primary school was 90 per cent for the poor and 95 per cent for the non-poor. The secondary net enrolment rate was 82 per cent for the non-poor but only 37 per cent for the poor. Lower quality education in the form of poorly adapted premises, lack of school material, poor training of teachers is concentrated in rural areas and marginal urban zones, precisely where the poor are to be found. As a result the poor are more likely to repeat years as well as to drop out of school early, particularly secondary school.

Public spending in education is high in Panama, 5.6 per cent of GDP in 1997, an increase from 4.7 per cent in 1992. This is higher than the average in Latin America (3.6 per cent of GNP) and higher than the average in industrialized countries (5.3 per cent of GDP). Yet public spending in education is highly regressive in Panama. Spending in primary education is equivalent, as a proportion of total spending, to spending for university level that benefits almost exclusively the non-poor. The poor represent 43 per cent of the school age population (5-24 years), but receive only 28 per cent of total public spending on education. Likewise, the urban population of school age represents almost half of the total population but receives over 75 per cent of total public spending.

Table 18: Public spending in education

\begin{tabular}{lll}
\hline & 1992 & 1997 \\
\hline Total spending as \% of GDP & 4.7 & 5.6 \\
Spending as \% of total in & & \\
Primary & 40 & 29 \\
Secondary & 25 & 33 \\
University & 29 & 30 \\
Other & 6 & 8 \\
Source: World Bank, 2000 & & \\
\hline
\end{tabular}


Public spending in primary education is progressive as it benefits proportionately more to the poor. Its coverage is close to universal although improvements are still possible, both in terms of coverage and in quality. But this is not the case for spending in secondary education (33 per cent of total spending) and higher education. University education is free in Panama but benefits disproportionately only the higher income groups. The coverage and quality of secondary education is wanting. By comparison, public spending in education in Singapore in 1985-86 was concentrated on primary and secondary education (over 67 per cent), with less than 30 per cent going to tertiary education. The share going to higher education has proportionately increased as Singapore achieved universal secondary school enrolment. Panama has chosen to raise the share of expenditures going to tertiary education when enrolment rates in secondary school where far from universal.

It is interesting to compare the educational profile of the labour force in Latin America and in Asia (Morley, 2001). Latin America has a higher share of university graduates (as a proportion of the adult male population) than most countries in Asia save Korea and Taiwan. But no country in Latin America equates the share of complete secondary schooling observed in Malaysia, Korea and Taiwan. Where Asia moved to complete secondary schooling following universal primary education, Latin America directed its efforts toward raising the supply of university graduates. Increasing the supply of secondary school graduates has narrowed the wage differential in Asia, whereas in Latin America raising the supply of university graduates has enlarged the wage differential. These diverging educational strategies not only translate into different patterns of educational and income inequality, rising in Latin America and falling in Asia. They also have direct implications for economic growth, particularly in the case of open economies dependent on exports. It has long been observed that openness had the effect of widening the wage differential between high and low skilled workers, putting a premium on skilled workers. If the supply of skilled workers is constrained, then wages will tend to increase at the same time as enterprises in the export sector as well as those competing with imports will seek to control wage costs to retain their competitiveness. A strategy to boost exports would therefore call for an expanded supply of skilled workers with completed secondary education. This is what happened in Asia, but not in Latin America.

An important objective for Panama is to aim for complete secondary schooling within the next decade, ensuring at the same time to raise the quality of education. Resources currently directed to university education need to be diverted towards primary and secondary schooling. An important objective would to ensure that children of poor families enrol in and complete basic education, possibly with some subsidies to cover the costs incurred.

\section{(iv) Vocational training}

Any economy that is opening up to the global economy is bound to face a demand outstripping supply in a range of new skills as well as bottlenecks for skills for which demand may be declining. A number of issues are here intermingled. One is the overall educational level of the workforce, which as seen above, has been rising on average, but is heavily biased against lower income groups, the major purveyors of low and unskilled labour. Another concerns the tools to assess what future demand for skills is likely to consist of. There are no well-established methodologies to assess future demand for skills, save by regularly surveying opinions of persons closely linked to the market for goods and services, including the market for training services. Chambers of commerce, employers' organisations, individual entrepreneurs and training institutes are the more likely candidates for such polls to be taken preferably on a regular basis. Finally, there is the capacity of training institutions to adapt their services to changing market requirements. 
This is possibly the most difficult task given the well-known institutional constraints faced by service providers who may not be directly dependent on the market.

As in most Latin American countries, there exists in Panama a national vocational training institute (INAFORP) funded by a levy on the private sector wage bill. This immediately presents a problem in that the institution is assured of a certain level of funding and decides on the allocations of its budget. In principle, the representation on its board of employers and workers' organisations should allow it to maintain a close link to the demand for skills. In practice, training activities are largely decided by existing supply capacity. This is a recognized problem in most such institutions. One possible alternative, as has been suggested in the case of the vocational training institution in Colombia, is to separate training providers from training funders, requesting the former to compete for their services directly from enterprises, or through an institutional mechanism that would allow enterprises to decide more directly where they wish to spend their training funds. The ILO has made such proposals for the reform of the vocational training institution in Colombia (ILO, 1999). These have not yet been adopted, but have led to a very rich and timely debate about alternatives to the funding of training services.

Over the period 1995-98, INAFORP has trained some 15,027 students on a yearly average, equivalent to 40.8 per cent of the average annual increase in the working age population (15 years and more). Women represented 39.8 per cent of all graduated students. However, upon closer scrutiny, it appears that only a low 1.4 per cent of all students followed a full year course. Students in very short courses of less than 80 hours in total represent 45.8 per cent of all students over the same period. The remaining majority of students (52.8 per cent) have followed courses of less than 300 hours (approximately two months). Possibly more than simply duration, content and methodology of training need to be reviewed. Only a very small number of students are currently enrolled in a new dual training system, combining study and practice in enterprises (Rosal, 1999). The overall training effort is therefore relatively modest, compared to what would be required. The potential demand for training, including re-training, could be approximated to 15 per cent of the employed population of 25 years and more, or some 117,000 persons annually. In OECD countries, the mean number of hours of training per employee per year is above 45 hours $(O E C D, 2000)$. The participation rate in job related training (employed population 25 years and more) for ten countries averaged 35.6 per cent over 1994-95. No equivalent data are available for Panama.

Next to INAFORP, there are a number of other programmes providing training, as well as several private training institutions. It is not possible to quantify the total existing training effort carried out in Panama, but clearly it is well below what could be considered a minimum. The inequities observed above in access to basic education render vocational education more difficult and costly. A special programme run by the Ministry of Labour for disadvantaged youths aims to provide them with basic vocational training in semiskilled occupations, with 3 months in-class and 3 months as apprentices in enterprises. This approach, widely used in other countries in the region (Chile and Peru for instance), is proving quite effective. But capacity is limited and funding as well.

Clearly Panama needs to step up its vocational training efforts. The first priority should be to better spend what funding is available, which is substantial, on the basis of a better knowledge of the demand and supply of skills in the labour market. Panama does not currently dispose of an apex vocational training body responsible for defining training policy. In particular, certification of skills training, provided by private and public entities is urgently required. Participation of employers and workers as well as other social bodies, would greatly enhance the capacity to identify a clear policy and to push for the required reforms 
Income distribution is known to be highly unequal in Latin America relative to other regions and Panama is no exception. The Gini coefficient of income inequality for the year 1999 in Panama places it among the most unequal countries in Latin America and hence of the world. The poorest 40 per cent of the population receive approximately one-eighth of total income, whereas the share going to the richest 10 per cent is close to 40 per cent. This pattern has worsened in Panama during the 1990's with an increase in the share of total income going to the top 10 per cent.

Table 19: Income distribution

\begin{tabular}{lccc}
\hline & Colombia & Costa Rica & Panama \\
\hline Gini coefficient & 0.572 & 0.473 & 0.557 \\
Pop. with income $50 \%$ below medium & 46.6 & 36.1 & 46.4 \\
Pop. with income $50 \%$ below mean & 21.8 & 20.7 & 23.7 \\
Share in total income of & & & \\
$40 \%$ poorest & 12.3 & 15.3 & 12.9 \\
$10 \%$ richest & 40.1 & 29.6 & 37.1 \\
Source: CEPAL, Panorama Social de America Latina, 2000-2001 & & & \\
\end{tabular}

Morley (2001) finds three main reasons to the high and persistent income inequality in Latin America. The first is a pattern of investment in education skewed towards higher learning, thereby further concentrating human capital to the detriment of the large cohorts who fail to enter or complete secondary education. Technology and trade are pushing labour demand toward higher skill content. Yet Latin America and Panama in particular are still allowing large numbers of people to enter the labour market with only minimal skills, thereby rendering further training more difficult and costly. Second, Morley links unequal land distribution to rural-urban migration and the large urban low-wage low-skill sector, as a major explanatory factor in the regressive income distribution pattern. Insufficient growth and over-supply of unskilled labour have pushed wages and labour earnings downwards. Third, Morley finds that Latin America's income distribution pattern is closely linked to the disproportionate share of the top 10 per cent of the population, a group much richer relative to the mean than in most other countries. This pattern is also a characteristic of Panama.

Does income inequality have any effect on the rate of growth of an economy? The well-known Kuznets hypothesis, suggesting an inverted $U$ pattern of income inequality across development stages, is increasingly put to question. Indeed, various analysts have argued that either very low or very high levels of income inequality have a negative effect on economic growth. In a recent study Cornia and Court (2001) suggest that income inequality as measured by a Gini coefficient above 0.40 could have negative implications for higher growth, in addition to costs related to crime, political instability, deterred investment and the like. There is also evidence suggesting that income inequality and job satisfaction are negatively related, higher levels of wage inequality fuelling greater job dissatisfaction (Hamermesh, 1999). 


\section{International labour standards}

Panama is a founding member of the ILO and has to date ratified 74 Conventions, of which 68 are in force. Panama has ratified all conventions considered fundamental by the Declaration on Fundamental Principles and Rights at Work, including the more recent Worst Forms of Child Labour Convention, 1999 (No. 182). Between 1987 and 2001, there have been 19 cases concerning Panama submitted to the attention of the Committee on Freedom of Association, as well as 18 individual observations to Panama from the International Labour Conference Committee on the Application of Conventions and Recommendations, as well as 105 individual observations on the part of the Expert Committee on the Application of Conventions and Recommendations (CEACR). The observations on conventions that are not due for revision or considered obsolete amount to 47 , as presented in the following table.

Table 20: CEACR observations by convention (1987-2001)

\begin{tabular}{|c|c|c|}
\hline \multicolumn{3}{|c|}{ Freedom of association: } \\
\hline No.87 & 10 & \\
\hline \multicolumn{3}{|c|}{ Collective bargaining: } \\
\hline No.98 & 7 & \\
\hline \multicolumn{3}{|l|}{ Forced Labour: } \\
\hline No.29 & 6 & \\
\hline No. 105 & 2 & \\
\hline \multicolumn{3}{|l|}{ Indigenous people's: } \\
\hline No. 107 & 5 & \\
\hline \multicolumn{3}{|l|}{ Working time: } \\
\hline No.30 & 4 & information only \\
\hline No.89 & 3 & information only \\
\hline \multicolumn{3}{|l|}{ Wages } \\
\hline No.94 & 6 & \\
\hline \multicolumn{3}{|l|}{ Labour inspection: } \\
\hline No.81 & 1 & \\
\hline \multicolumn{3}{|l|}{ Maternity protection: } \\
\hline No. 3 & 3 & \\
\hline Total & 47 & \\
\hline
\end{tabular}

Source: ILO

An observation on the part of the CEACR ranges from an acknowledgement of the receipt of a report to the repeated suggestion on the modification of national legislation or practice. Ten observations concern the application of the Freedom of Association Convention, and eight forced labour matters. A large number of individual observations bear on maritime conventions in consideration of the large merchant fleet operating under Panama's banner, and the consequently large number of seafarers whose working conditions depend on Panama's law and regulations. Panama, as is well known, has a large merchant fleet. In 1999, 7.1 per cent of the world's merchant fleet was registered under Panama flag, representing 19.4 per cent of total merchant fleet tonnage. Ship owners in Japan effectively own 40 per cent of vessels registered in Panama (ILO, 2001c).

Most of the seafarers would not be Panama nationals, but this situation reflects negatively on Panama's international standing. 


\section{Social Dialogue}

There are some 26 employers' organizations represented in an apex federation of private enterprise (CONEP). Some 7 trade union federations are represented in an apex body (CONATO) representing the workers. The union density rate is 21.1 per cent of the labour force at the end of the 1990's according to some sources (Rueda-Catry, 2002), and 11 per cent in 1997 according to another source (World Bank, 2000). Close to 60 per cent of total union membership comes from public sector workers.

Employers' and workers' organizations are represented on various bodies such as the minimum wage commission, the national vocational training institute (INAFORP), the Social Security Agency and the InterOceanic Authority (ARI). Since 1992 employers and workers have joined forces to create a Labour Foundation responsible for providing technical assistance and training in labour matters and social dialogue in particular. In addition, various political and dialogue processes have been attempted during the 1990 's to bring employers and workers closer, such as the Bambito consultations initiated in 1993. The first Bambito consultations led to the adoption of a common declaration of principles. Similar consultations have been held later and various national dialogue processes are still going on

However, in spite of such consultations, when employers' and workers' organizations were requested to enter into consultations and negotiations with the government on matters of direct interest, such as the reform of the labour code in 1995, the adjustments to the minimum wage in 1998 and in 2000 in particular, and the reform of the social security, so far no agreement has been possible. The government has tended either to take decisions unilaterally or to postpone decisions, such as on social security. Whether the environment for social dialogue must change for it to play a useful role or whether social dialogue can be a force in shaping a new environment is a matter open for discussion.

\section{Strikes}

There has been an average of 2.4 strikes per year over 1991-2000. There were 9 strikes in 1999, 8 in 1996 but none in 1991 and 1993. The average number of workers involved was close to 33,000 . This is equivalent to 5.6 per cent of the average wage employed population. But this is largely due to a major conflict in agriculture in 1998 that mobilized close to 263,000 workers. The average number of days lost per year due to strike action amounts to 228,176 , that is 378 days per 1,000 wage worker per year or 1.3 days per wage worker per year on average. 
Compared to other countries in the region, Panama does not appear to be laden with a large number of strikes, quite to the contrary.

Figure 10: Strikes ands strikers per year

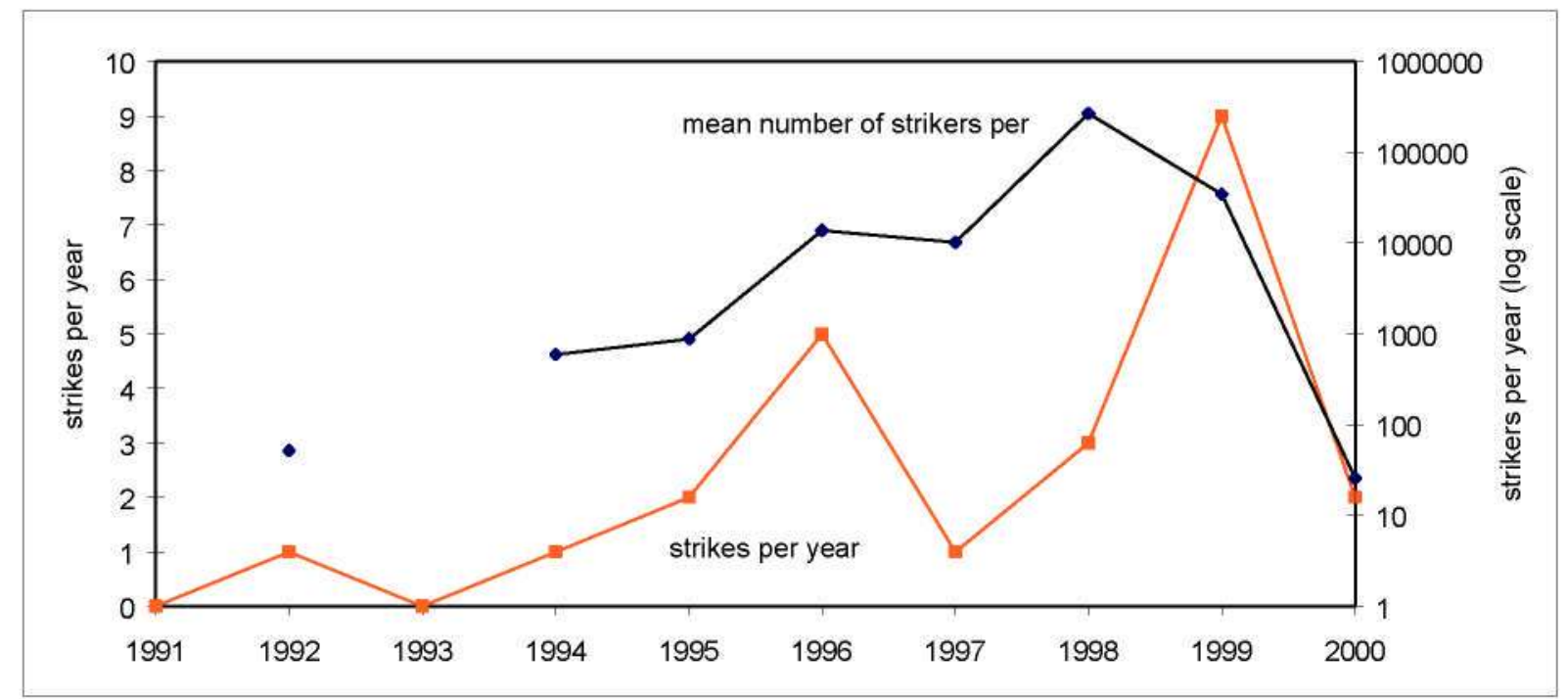

Source: ILO, Yearbook of Labour Statistics, 2001

\section{Policy options for Panama}

The growth performance of Panama's economy during the 1990's, with respect to overall GDP and per capita income, has been much better than during the previous decade. However, the growth rate of GDP declined from an average of 6.5 per cent during 1990-94 to 3.5 per cent during 1995-2000. Economic growth has been insufficient to significantly reduce poverty and to raise the quality of employment. A GDP per capita growth of at least 2.5-3 per cent over a fairly long period would be required in order to make any serious dent into poverty and generate employment at a level and of a kind to raise living standards.

Panama has opted to open its economy in a period of lacklustre growth. So far this has widened the deficit on the trade balance, without significantly boosting exports. This result raises a more general point on the link between openness and growth.

It is widely believed today that openness of an economy is invariably associated with higher rates of economic growth. Yet even though many countries have demonstrated that high rates of economic growth can be sustained through a close integration with the global economy, there is little evidence suggesting that growth and openness are causally related. Economic growth is primarily determined by the levels of savings and investment, and by estimated returns on future investment as perceived by investors, in relation to the cost of borrowing. In fact, the experience of many countries that have successfully integrated the global economy, from China to Singapore or Mauritius, shows that they started building an export capacity long before they opened their economies to competition from imports. Export industries grew behind protective barriers and opening was only gradual, much in the same way today's industrialized countries built their export industries. As Rodrik (2001) argues, there are few countries that have sustained high rates of economic growth without a rising share of foreign trade in total output. Conversely, few countries have been able to significantly increase their rate of growth simply by lowering their tariff barriers. It is the combination of domestic determinants to investment, with export promotion measures that account for a successful strategy. 
The fast growing economies of East and South-East Asia have shown a path combining rapid economic growth with a high growth elasticity of employment, a high rate of growth of labour productivity allowing for rising real wages and a sustained decline in the incidence of poverty. This combination was based in particular on a sustained expansion of productive employment in agriculture and in manufacturing. In contrast, Panama has only experienced moderate growth, with a high output elasticity of employment, but with low and falling levels of labour productivity. As a result, labour moved out of agriculture (where levels of labour productivity have increased but total output only moderately) into services at very low levels of productivity and remuneration. Poverty may have declined during the 1990 's, but remains at a very high level at the end of the decade. Employment has clearly not been the means by which to reduce poverty.

It is essential for Panama to achieve rates of aggregate economic growth around 5-6 per cent per year in order to generate a sustained increase in productive employment. This can be achieved with higher levels of investment in those sectors most likely to induce a greater utilization of the labour of the poor, primarily agriculture, manufacturing and construction. But it is equally important for the poor to be able to contribute to higher levels of economic growth by facilitating their access to productive resources, primarily land, credit, physical infrastructure as well as health and education facilities that will raise the human quality of the poor's labour.

Such an overall strategy for growth, employment and poverty alleviation has not yet been articulated in Panama ${ }^{8}$. It would directly respond to the principles enunciated in the Employment Policy Convention, 1969 (No. 122) ratified by Panama along with 90 other countries which determines inter-alia, that ratifying States shall "...pursue, as a major goal, an active policy designed to promote full, productive and freely chosen employment".

An application of this principle would require serious considerations of at least the following five policy areas.

The first is the composition of output, specifically the neglect of agriculture and industry. Panama cannot afford to turn its back on two sectors that could significantly enhance their contribution to total exports and employment, even though they now represent respectively 15 and 9 per cent of the total labour force. Faster growth in agriculture would significantly contribute to more rapid reduction of poverty. This would depend on a significant increase in the level of public investment in infrastructure in rural areas, as well as in basic services, technical assistance and credit. An appropriate mix between small scale and large-scale agriculture would be required. Appropriate land titling procedures would also help. Likewise faster growth in the manufacturing sector would greatly enhance its employment generation capacity, thereby reducing the number of poor quality jobs in the informal sector. This would require raising its capacity to export through a number of WTO-compatible public support measures. It would also imply providing far greater support to small enterprises than is the case at present

Any export strategy would be dependent on a number of conditions regarding infrastructure, skills level of the workforce and wage costs. It would also depend on access to information on markets, regulatory aspects, technology, attendance to trade fairs, exchanges with best practice enterprises and the like.

In 1974 the ILO produced a major report on employment in Panama, the conclusions and recommendations of which are very much in line with those of the present paper. In particular employment in agriculture, the employment implications of skewed spatial development as well as the place of employment in the overall macroeconomic policy were discussed. 
A second area is education and training. Universal secondary enrolment should be Panama's objective for the present decade. This would imply shifting resources from university education to secondary education, in order to broaden coverage and substantially raise enrolment rates and the quality of teaching. This would imply a reconsideration of the employment and working conditions of teachers. Some reform in the training system would be required in order to ensure a better link with evolving demand in skills as well as to significantly raise the number of workers in either initial or continuing vocational training. One option would be to offer all interested youth with a training opportunity of at least 6 months, followed by a temporary position as an apprentice in an enterprise. A national tripartite agreement could define the framework within which such an objective could be met.

The third area concerns labour market policies. Wage adjustments can no longer ignore that the economy is now fully open. Such adjustments will immediately affect the competitive position of Panama, which has no autonomous monetary policy. Wage adjustments have to be decided in relation to adjustments made in countries trading with Panama, as well as on the basis of increases in labour productivity. This implies taking specific measures to stimulate sustained rises in productivity, as well as a capacity to measure trends in productivity at the national level, but also at the sectoral level as well as at the firm or workplace. There is much international literature and experience on this issue that can be drawn upon (Prokopenko and North, 1996). One simple way is to better link wages to actual performance. Far greater transparency in the labour market with respect to vacancies and job seekers would be required. At present, there is no system by which to measure vacancies, nor for potential employers to assess job seekers. Some labour market intermediation system should be introduced. There are many examples on which to draw upon.

Fourth, there is the issue of social protection. Universal coverage is within Panama's reach and should be considered a major objective. This may imply finding more flexible modalities for the self-employed. The financing of social protection has evident macroeconomic as well as microeconomic implications, specifically in terms of the active/inactive ratio, the schedule of benefits as well as by overall labour market conditions. Obviously, a rise in the employment rate would greatly contribute to the financial viability of the social security system. This would imply in particular measures to facilitate the access of women to the labour market. Contributions to social security obviously represent a cost that needs to be accounted for in the competitiveness of the economy. But the security that social protection can provide will be an important asset in facilitating changes between jobs, in stimulating the workforce and in enhancing an overall sense of security. Social protection has a role to play in poverty alleviation. Specifically, a benefit could be provided to low-income mothers on the condition that children attend school. The effectiveness of this approach has been proven in several countries (Lavinas, 2001). The Government should also consider adopting a basic tax-financed pension scheme for all elderly persons without the benefit of a pension. This could be means-tested and directed to poor households.

Finally, there is the role of social dialogue. The basic question can be put very simply: is social dialogue seen as part of the solution, or part of the problem ? What would be minimal conditions for a fruitful dialogue between employers' and workers' representatives, and with the government? This can only be solved in terms of a negotiating agenda in which all three parties have a stake and in which all three can obtain significant results. The high income inequality observed in Panama is a sign of a weak social cohesion that bears directly on social dialogue. But social dialogue can be a means to decide on measures that could reduce such income inequality, particularly if high economic growth can be combined with sustained productive employment generation. Social dialogue and in particular wage and social benefit negotiations are critical in such a 
context. The experience of countries that have moved along such a path could usefully inspire social actors in Panama.

A policy package such as the one discussed above focused on decent work holds the promise of strengthening the foundations of economic growth and social development in Panama in the context of globalisation. However, any debate about policy options for Panama has to be carried out in Panama among the relevant representative bodies and in the appropriate fora, with the broadest possible consultations. It is hoped that this piece will at least stimulate such discussion. 


\section{References}

Berg, Janine and Taylor, Lance. 2000. External liberalization, economic performance and social policy. CEPA working paper No.12, February, New York.

CEPAL. 2000-01. Panorama social de América Latina. Naciones Unidas. Santiago.

CEPAL 2000. Amuario estadístico de América Latina y el Caribe. Naciones Unidas. Santiago.

Cornia, Giovanni Andrea, and Court, Julius. 2001. Inequality, growth and poverty in the era of liberalization and globalization. United Nations University and WIDER. Helsinki

De Jong, Niek and Vos, Rob. 2000. Economic reforms and rising inequality in Panama in the $1990 \mathrm{~s}$. Institute of Social Studies, Working Paper Series No. 138, June. The Hague.

Hamermesh, Daniel. 1999. The changing distribution of job satisfaction. NBER working paper No. 7332. Cambridge. http//www.nber.org/papers/w7332

ILO. 1974. Situación y perspectives del empleo en Panamá. Geneva.

ILO. 1982. Resolution concerning statistics of the economically active population, employment, unemployment and underemployment, adopted by the Thirteenth International Conference of Labour Statisticians, Geneva, October.

ILO. 1998. Valuación financiera y actuarial integral de la Caja de Seguro Social y elaboración de un modelo de cuentas sociales. Geneva and San José.

ILO. 1999. Empleo, un desafio para Colombia. Lima.

ILO. 2000. Review of annual reports under the follow-up to the LLO Declaration on Fundamental Principles and Rights at Work, Governing Body, $277^{\text {th }}$ Session, March, Geneva.

ILO. 2001a. Social Security: A new consensus. International Labour Conference, $89^{\text {th }}$ Session, 2001. Geneva.

ILO. 200lb. Trade Liberalization and employment. GB.282/WP/SDG/2. November. Geneva.

ILO. 2001c. The impact on seafarers' living and working conditions of changes in the structure of the shipping industry. Report for discussion at the $29^{\text {th }}$ Session of the Joint Maritime Commission. Geneva.

ILO.2002. Decent Work and the Informal Economy. International Labour Conference, $90^{\text {th }}$ Session, Geneva.

Jiménez, Félix. 2001. Crecimiento, politica económica y empleo: Evolución y perspectives de la economia panameña. Julio. Panamá.

Lavinas, Lena. 2001. The appeal of minimum income programmes in Latin America, Socioeconomic security working paper No.7, Geneva, ILO 
Mesa-Lago, Carmelo. 2000. Informe sobre la reforma de la seguridad social en Panamá. Fundación Friedrich Ebert, Marzo, Panamá.

Morley, Samuel. 2001. The income distribution problem in Latin America and the Caribbean. United Nations, Economic Commission for Latin America and the Caribbean. Santiago.

Prokopenko, Joseph and North, Klaus (eds). 1996. Productivity and quality management: a modular programme. ILO and Asian Productivity Organization, Geneva.

OECD. 1998. Employment Outlook. Paris.

OECD. 2000. Employment Outlook. Paris.

OECD. 2002. Employment Outlook. Paris

Rodrik, Dani. 2001. The global governance of trade as if development really mattered. UNDP. New York.

Rosal, Hugo. 1999. Estudio sobre la formación professional en Panamá. Unpublished mimeo. ILO.

Rueda-Catry, Marlene. 2002. Diálogo social en Panamá: el camino hacia la democracia. ILO. Geneva.

Todaro, Michael. 1971. "Income expectations, rural-urban migration and employment in Africa" in International Labour Review Geneva 104(5), Nov. 1971, 387-413

Singh. Ajit. 1997. Catching up with the West: A perspective on Asian Economic development and lessons for Latin America in Economic and Social development into the XXI Century Louis Emmerij Editor, Inter American Development Bank, 1997, Washington D.C.

Tokman, Victor, and Martinez, Daniel. 1999. Flexibilización en el margen: La reforma del contrato de trabajo. ILO. Lima

United Nations. 2001. World Economic and Social Survey. New York.

World Bank. 2000. Panama: Estudio sobre pobreza: Prioridades y estrategias para la reducción de la pobreza. Washington D.C. 